\title{
Systematic Review of the Factors Impacting the Agro-processing Sector Towards Economic Growth \& Development: A Case for Ghana
}

\author{
Edmund Gyandoh \\ University of Maryland Global Campus, College Park, Maryland, USA
}

\begin{abstract}
In Ghana, the processing of agricultural raw materials into intermediate and secondary, agro-processing, is largely small-scale and informal. Formalizing and expanding the agro-processing sector to increase the share of manufacturing value-add (MVA) on the Gross Domestic Product (GDP) of Ghana is an ongoing struggle. It is also unclear what the impeding growth factors are and what the leaders of Ghana are doing to rapidly fix this fundamental economic problem. This study aimed at bridging the gap between evidence-based research (EBR) and practice to fundamentally understand the growth factors that impact the agro-processing sector of Ghana towards economic growth and development. EBR is a scientific process of gathering the best available evidence to inform evidence-based practice (EBP). EBP requires the use of scientific, accountable, and explicit methods to gather credible and quality evidence for management decision-making. The systematic review methodology, which fits the rationale for EBR, was used to aggregate credible, quality, and best available evidence to help leaders in Ghana and management practitioners to make decisions on why the agro-processing sector of Ghana is still weak and undeveloped today, despite being known as a haven for agricultural raw materials. Thematic synthesis was used to aggregate evidence from 31 included articles, resulting in 7 analytical themes that directly addressed the overarching research question, "What growth factors impact the agro-processing sector of Ghana for economic growth and structural transformation". Theme 1 categorized the growth factors impacting the agro-processing sector into 17 endogenous (e.g., knowledge management, technology, and innovation capability, access to capital, etc.) and 3 exogenous concerns (e.g., the influence of external organizations (e.g., International Monetary Fund (IMF), Foreign Direct Investments (FDI), etc.). Themes 2-7 addressed aspects of economic growth and structural transformation. Though this study was limited by time and the databases used to search for relevant scholarships, it rigorously informed management decision-making on how the agro-processing sector could be used to drive economic and structural transformation in Ghana and other resource-rich developing countries across the globe. Keywords: Agro-processing, Economic growth, Structural transformation, Economic development, Developing countries, Ghana, Gross Domestic Product (GDP), Growth factors, Manufacturing value-add (MVA), Evidencebased Research (EBR), Evidence-based Practice (EBP), Systematic Review (SR).
\end{abstract}

DOI: $10.7176 / \mathrm{JESD} / 13-2-08$

Publication date: January $31^{\text {st }} 2022$

\section{Introduction}

This evidence-based research (EBR) examined the factors influencing the agro-processing sector, a subset of the formal manufacturing sector of Ghana, towards economic growth and development. The findings from this study inform evidence-based practice (EBP), by helping the government of Ghana understand and make management decisions on why the agro-processing sector of the country is weak and undeveloped despite being a haven for agricultural raw materials. Agro-processing is the conversion of agricultural raw (primary) materials to intermediate or secondary products. The problem is that, according to Ghana's Ministry of Agriculture, Ghana adds value to less than $10 \%$ (precisely only $5 \%$ as of 2012) of its abundant agricultural raw materials (Owoo \& Lambon-Quayefio, 2018). Why is that the case? This study used a scientific and accountable method to explicitly gather credible and quality evidence to address the problem of why the agro-processing sector of Ghana is still weak today. The overarching research question was: \section{transformation?}

What growth factors impact the agro-processing sector of Ghana for economic and structural

Ghana is a developing country in Sub-Saharan Africa with a Gross Domestic Product (GDP) of $\sim \$ 72.35$ billion, a world bank recorded annual growth percentage of 0.414 , a population of $\sim 30.4$ million people, and a GDP per capita of $\sim \$ 2,200$ (World Bank, 2020; UNIDO, 2020). According to the Ghana Statistical Service (GSS) (2019), the major contributors to Ghana's GDP are Agriculture, Industry, and Service sectors. The Service sector holds the largest share of GDP, contributing $46.3 \%$ in 2018. The industrial sector is the second largest, contributing $\sim 34 \%$ share to the GDP, while agriculture is third and saw a decline from $21.1 \%$ in 2017 to $19.7 \%$ share of GDP in 2018. The sub-sectors of agriculture mainly involve raw material from crops (e.g., cocoa, cashew, etc.), livestock, forestry and logging, fishing, etc. The industry share of Ghana's GDP comprises mining and quarry (e.g., oil, minerals like gold, etc.), manufacturing, electricity, water and sewerage, and construction sub-sectors (Ghana 
Statistical services, 2019). The processing of agricultural raw materials (agro-processing) to food and other end products, for local and international trade, is a sub-element of the manufacturing industry of Ghana. Agriculture production and agro-processing are, together, a valuable asset to economic growth and development in countries across the world - suggesting an indispensable potential for economic growth since Ghana is a huge ecological environment (Nyamekye et al., 2021). The agro-processing industry, as a matter of direct consequence, adds to the total manufacturing value-add (MVA) of the country. It provides an opportunity for small-scale farmers to increase income, especially through self-processing, as well as diversify into agritourism and other agribusinesses (Lin and Hung-Hao, 2021). According to the World Bank Group, the manufacturing value add contributed $\sim 9.921 \%$ share to Ghana's GDP growth in 2020 (World Bank, 2020), suggesting that a strategic expansion of the agro-processing sector could have a direct impact on GDP growth through the expansion of production activities and boosting employment (Romanian et al., 2020). Though Ghana, since its independence in 1957, has made different strides through various government policies to improve the agro-processing sector of the manufacturing industry, the sector remains weak and underdeveloped (Owoo \& Lambon-Quayefio, 2018). Why is that the case?

According to UNIDO (2021), the service sector is first with over $40 \%$ contribution to the country's total manufacturing value-added, followed by agriculture and manufacturing at $21 \%$ and $12.9 \%$ respectively. Agroprocessing represents over $50 \%$ of the manufacturing value-add, with the food and beverage sub-sector contributing $\sim 33 \%$ (Nkechi S. Owoo \& Lambon-Quayefio, 2018). Deductively, the agro-processing industry contributes a little over $6 \%$ to the country's current GDP. Despite Ghana's agro-processing sector being dominated by small and medium scale capabilities, mostly in rural Ghana, there is potential to formalize and make a remarkable contribution to the economy, as demonstrated in some large economies in the world. In the United States, the world's largest economy, agriculture, food, and related industries contributed \$1.109 trillion (a 5.2 percent share) to its gross domestic product (GDP) in 2019 (United States Department of Agriculture, n.d.). The direct output of America's farms contributed approximately $\$ 136.1$ billion of this total, which is about 0.6 percent of GDP. The overall contribution of agriculture to the US GDP is greater than 0.6 because of agro-processing sectors - food services and eating and drinking places; food and beverage stores; food and beverage manufacturing; forestry and fishing; and textiles, apparel, and leather products, add value to raw or primary materials from the farms. Deductively, $\sim 90 \%$ of agricultural raw materials are processed from small to industrial-scale enterprises in the United States. The U.S manufacturing value adds for food, beverages, and tobacco was reported at $\sim 15.16 \%$ contribution to US GDP in 2011 (Census and Economic Information Center, n.d.), largely because of processing and adding value to agricultural raw materials. Ghana, on the other hand, has only 5\% of food harvested is processed through industries. Ghana has a huge ecological environment for agriculture production and a haven for raw materials, which are mainly exported to countries around the globe with little or no processing or manufacturing value-add. Today, economic growth, structural development, and modernization in Ghana, like other developing countries, remain a hot and ongoing topical issue. The problem is Ghana's obvious lack of robust and expanded agro-processing and manufacturing sector to formally convert its abundant agricultural raw (primary) materials into valuable secondary products for local and international trade.

Today, economic growth, structural development, and modernization in Ghana, like other developing countries, is a hot and ongoing topic. Ghana is a huge ecological environment that fosters continuous agricultural production - a strength. It is a haven for raw materials which are exported to countries around the globe with little or no processing or manufacturing value-add. Though there is an established linkage between agriculture, manufacturing, and GDP growth (Nyamekye et al., 2021; Owoo \& Lambon-Quayefio, 2018; Romanian et al., 2020; Zayone et al., 2020), the kind and type of decisions Ghana makes on agriculture and its abundant raw materials could make or break its future economic outlook. A vibrant agro-processing sector has the economic potential of reducing or eliminating the continuous and over-reliance on the importation of processed food products from the United States, China, Europe, etc. Given Ghana's abundant raw materials, the question that begs to be asked is how Ghana's agro-processing industry is doing today, and what should be done differently to boost manufacturing value add, cause GDP growth, and accelerate structural development. The purpose of this study is to use evidence-based research (EBR) to gather credible and quality evidence that addresses the problem of why the agro-processing sector of Ghana is still weak today and examine all contributing factors to why that is.

\subsection{Theoretical Background}

The research question (RQ) of this study is theory-based and it addresses the question about the impact of agroprocessing on Ghana's manufacturing sector for economic growth and development. The business case of how agro-processing influences manufacturing value-add, GDP growth, and economic development start with understanding the combined effect and application of a certain series of theories to establish a common characteristic or framework that never existed (shown in 2.1 below) (Lepine \& Wilcox-King, 2010; Okhuysen \& Bonardi, 2011). According to Salem Press (2017) and Brinkman (1995), economic growth and economic development differ in structure and form, though are often used interchangeably. Economic growth involves a complete shift and quantitative expansion in the economic and social framework of the nation. According to the 
world bank, it is the percentage increase in a nation's GDP per annum. Economic development, on the other hand, involves upscaling the social framework and systems, which is not limited to education, healthcare, power distribution, and cultural attitudes (Salem Press, 2017; Brinkman, 1995). It also involves moving resources from low to high productivity areas, a process involving a series of structural transformations (Zulkhibri et al., 2015). Though GDP growth alone cannot lead to structural transformation and economic development, economic growth cannot happen before the required infrastructural and institutional structures are in place (Salem Press, 2017; Brinkman, 1995). This implies that GDP growth and economic development (structural transformation ) need to be planned, executed, and matured together - the path to economic development could be measured with accelerated and aggregated economic growth and the thorough transformation of the economic and social infrastructures (Brinkman, 1995). One form of seeing this upward movement and metamorphosis (replication) of the social structure is continuously modernizing and upscaling infrastructure to process agricultural raw materials for economic growth - multiplying resources for manufacturing value-add (MVA) and industrialization of the country (Brinkman, 1995; Zulkhibri et al., 2015).

\subsection{Theoretical Lens}

\section{Theories of Economic Growth:}

There are two main theories of economic growth of developing countries that provide contextual relevance to this study: (1) neoclassical growth theory, and (2) new growth. The neoclassical theory is an exogenous theory that emphasizes productivity growth (production output) as a function of capital, labor, and a measure of technology growth factors external to the system (Robert Solow's basic equation) (Salem Press, 2017; Mankiw, 1995). However. the exclusive addition of capital to the national economy for economic growth and the assumption that the market system will ensure fair allocation of resources are inherent limitations of the theory. Another limitation of the theory is its inability to accurately predict the GDP per capita and population convergence of nations as developing (poor) countries tend to grow faster than developed (rich) countries (Salem Press, 2017; Mankiw, 1995).

Many researchers hold that the new growth theory, which is closely associated with American economist Paul Romer, is an endogenous growth theory and a direct response (as opposed) to the limitations of the neoclassical growth theory (Cortright, 2001). An endogenous growth emphasizes change starting from within. The theory believes that economic growth is created and sustained within the nation rather than influenced by external factors not limited to trade and foreign direct capital investments (Salem Press, 2017; Cortright, 2001). Additionally, the theory posits the importance of building knowledge and technology internally for increased economic returns creating large and small discoveries from a fixed set of raw materials to drive economic growth (Cortright, 2001). For example, literature shows China's entry into the World Trade Organization (WTO), over time, stagnated its dynamic economic growth efforts, while driving higher labor costs and welcoming various foreign direct investments (FDIs) (Yao et al., 2013). With rising income, expanded social infrastructure, coupled with great advances in technology and knowledge, China drew in investors looking for new markets, leading to a bounce back to economic growth and prosperity (Salem Press, 2017; Yao et al., 2013). Economic growth of nations, as facilitated by its endogenous factors and capabilities, is therefore important for economic development, evidenced by structural transformation and industrialization. Total dependence on foreign direct investments to drive all internal economic activities and cause the needed structural transformation is not helpful to developing countries in the long term - there is a need to balance the use of internal (endogenous) and external (exogenous) drivers for economic growth and development until the desired economic maturity is attained.

Modernization and structural change theories also provide contextual relevance to understanding the factors impacting how agro-processing can be leveraged for economic growth and structural transformation. Many researchers have confirmed causality between sustained economic growth and modernization through structural transformation and industrialization of societies (Omolara, 2019; Zulkhibri et al., 2015). Modernization theory emerged in the 1950s and 1960s. Marsh (2014) proposed that a country's level of modernization, as measured by GDP per capita or energy consumption per capita or urbanization, may have a multidimensional aspect of social characteristics such as economic, political, cultural, and psychological. Marsh also asserted that the level of a country's modernization increases with increasing and continuous structural transformation (p. 279).

Modernization theory, nonetheless, over the years, has seen various extensions and revival due to various researchers' intention of fixing observed anomalies in the areas such as understanding its link to evolution theory (Newson and Richerson, 2009; Marsh, 2014), ecological modernization (Levy,1966), risk society (Beck, 999; Marsh, 2014), reflexive modernization (Ulrich Beck 1992; Beck et. al, 1995; Marsh, 2014), values modernization, global modernity (Schmidt, 2010:2011:2012; Marsh, 2014), just to mention a few. Modernization of a society can take an endogenous growth approach, making modernization theory the most suited theoretical basis to support this study. It casts development as a uniform evolutionary route that all societies follow, from agricultural, rural, and traditional societies to post-industrial, urban, and modern forms (Bradshaw, 1987; Escobar, 1995; Chirot and Hall, 1982).

Though often regarded as too deterministic, modernization theory posits that the required economic and social 
transformation of developing nations and poorer societies, can be tracked in different structural stages (Salem Press, 2017; Gwynne, 2009; Mankiw, 1995; Zulkhibri et al., 2015). According to W.W. Rostow, the sequence of economic and developmental stages of a nation was pre-determined as follows (Rostow, 1951; Chirot and Hall, 1982: 82):

(1) Traditional Economies: Typically, the structures in these societies are developed with limited production capabilities - the Newtonian belief that the external world "was subject to knowable laws and is systematically capable of productive manipulation" (Rostow, 1951). Though these economies are in no way static, they are characterized with but are not limited to low levels of urbanization, low education, poor transportation, high dependence on subsistence and agriculture, with ad hoc technical innovations to improve production output (Coman et al., 2012; Hunter, 2012; Omolara, 2019; Rostow, 1959).

(2) Transition to takeoff (under-developed economies (Hunter, 2012)): These are societies typically characterized by simple infrastructure, adoption of basic agricultural techniques, very high dependence on imports, unsegmented and fragmented markets, reliance on natural resources, attracting foreign aid and investments. According to W.W. Rostow, a rise in the effective investment and savings to over $10 \%$ or more. The informal sector is large.

(3) The takeoff itself (Developing economies (Hunter, 2012)): New industries expand rapidly, yielding profits, and stimulating re-investments in new plants and other modern industrial plants, paving way for the increased requirement for workers, coupled with increased services and manufacturing to support the growing population. There are growing investments but there is dependence on developed countries for imports. It requires access to markets. The manufacturing sector is growing but is largely informal in nature. Commercialization of agriculture increases and manufacturing value-add increases as agro-processing (processing of agricultural raw materials like timber) increases. Importation of processed food and beverages decreases. The political and social structures of these developing economies are transformed over time. There is a desire for high market concentration and drive (4) Drive to maturity: It is characterized by the nation's ability to move beyond the original industries which powered its take-off (Rostow, 1951), demonstrating the technological and entrepreneurial capability to produce whatever it chooses. Technology and industry become complex and any observed changes in the domestic economy are typically attributed to technology and industrialization. Imports, for instance, are replaced by domestic production and manufacturing and there are increased exports and access to international markets exports exceeding imports. There is also increased diversification, specialization, innovation, and investments towards economic stability.

(5) Age of high mass consumption: Here, there is a shift towards durable consumable goods and services - a consumer-oriented economy. As the income per head increases, savings and consumption increase. Increased savings resulting from a stable savings rate typically displace consumption and cyclically become a source for business investments.

Developing countries desire to have high economic growth but that process lacks spontaneity and automation (Riaz et al 2020). As described above, structural transformation forms an integral part of modern economic growth theory, making structural change theory relevant to this study. Structural change, as defined by Van Neuss (2019) in Riaz et al. (2020), is the "reallocation of economic activity across the three broad sectors agriculture, manufacturing and services." One major aspect of structural change theory, which involves the shift of labor from agriculture to industries, is not limited to agro-processing and/or agro-based manufacturing (Kuznets, 1973; Lewis, 1954).

Additionally, with an endogenous economic growth mindset, developing countries, given the abundance of agricultural raw materials can begin processing and adding value for modern economic growth. To formalize agroprocessing and agro-based manufacturing requires deliberate structural transformation, evidenced through rapid industrialization - the springing up of industries including agro-based processing facilities. The conceptual model below is based on economic growth (neo-classical growth and new growth), modernization, and structural change theories, and shows how the relationship between agro-processing or agro-based manufacturing, total manufacturing value add, and industrialization leads to sustained economic growth and development (structural transformation) - a take-off to economic to maturity. The concept areas are (1) factors impacting agro-processing, (2) how agro-processing increases manufacturing value-add, (3) how agro-based manufacturing value- add cause economic (GDP) growth and drives structural transformation (industrialization), and (5) take-off to economic maturity. 


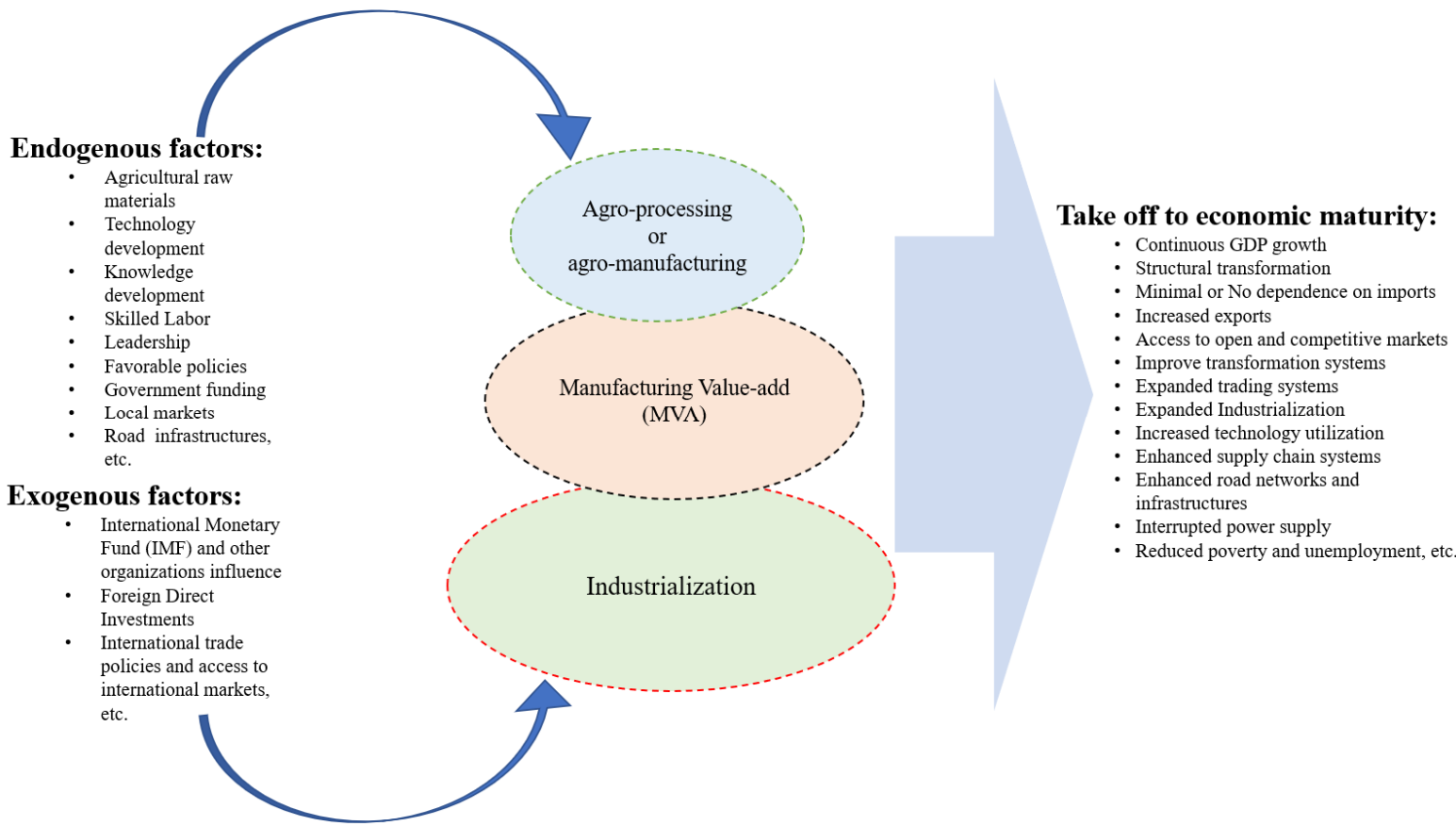

Figure 1: Conceptual model of how agro-processing can drive manufacturing value-add, engendering endogenous economic growth and structural transformation through (Gabardo et al., 2017; Kuznets, 1973; Lewis, 1954; Riaz et al., 2020; Rostow, 1959; van Neuss, 2019)

1.1.1 Heading 3

\section{0 Methodology}

This evidence-based research (EBR) examined the factors impacting the agro-processing industry of Ghana towards economic growth and development. EBR leads to credible and quality evidence, required by leaders of developing nations and management practitioners to make effective decisions on which factors impact a developing nation's economic growth and development. The process of rigorously gathering and synthesizing the required, quality, and most appropriate evidence possible to answer a research question (RQ) is evidence-based research (EBR) (Titler, 2008). The purpose or rationale for an EBR approach is to inform evidence-based management (EBMgt) and Evidence-based practice (EBP). EBP enables practitioners to support decisions with quality, valued, and the most reliable evidence possible (i.e. the most appropriate information available) (Petticrew and Roberts, 2006; Kent et al., 1999). EBMgt is the process of "making decisions through the conscientious, explicit, and judicious use of four sources of information: practitioner expertise and judgment, evidence from the local context, a critical evaluation of the best available research evidence, and the perspectives of those people who might be affected by the decision" (Briner et al., 2009, p.19). The integration of EBR and EBMgt helps practitioners and researchers to solve complex management and organizational challenges through a well-defined and practical course of action. The cornerstone of EBMgt is a systematic review (SR) (Briner et al., 2009). An SR uses scientific, systematic, explicit, and accountable methods " to comprehensively identify, appraise, and synthesize all the relevant studies on a given topic," instead of a single study, to answer a research question (Petticrew and Roberts, 2006, p.15-19; Gough et al., 2012). The utilization of the EBR framework for this study makes an SR the best and appropriate design choice for this study. The rationale for choosing SR is inherent in its contribution of rigor and transparency to the process of reviewing and gathering credible and quality evidence to support decision-making. It bridges the gap between research and practice. SRs exposes studies to rigorous scientific and methodological scrutiny (Tranfield et al., 2003). Scientific rigor is the backbone of an SR. It also adopts a detailed, replicable, and transparent process that aims at minimizing bias by providing an audit trail of the reviewer's decisions, procedures, and conclusions (p. 209). Other traditional methods were not considered for the lack of rigor and transparency.

Therefore, to find the best and credible evidence-based solutions for the problem posed in this study, a SR was conducted to bridge the gap between research and practice. A SR of scientific literature on the factors that impact the agro-processing sector for economic growth and development was conducted with the required rigor, transparency, and accountability while limiting bias. The objective, comprehensive, rigorous, and transparent nature of the SR projects confidence in the quality and credibility of the evidence gathered on the agro-processing industry towards the economic growth and development of Ghana. A SR can use either aggregative or configurative logic in the review process. This study employed an aggregative approach because it sought to gather 
and add up (aggregate) evidence from studies that support each other on the factors (interventions) that impact agro-processing in developing countries, in this case, Ghana (Gough et al., 2012). Configurative SR logic, on the other hand, interprets and arranges (configures) information and develops concepts.

The systematic review (SR) employed a Six (6) stage modified approach from Pollock \& Berge (2018) and Nurmala et al.(2017) to explicitly gather and synthesize credible and quality evidence to address the problem statement.

Stage One - Formulating research question (RQ)

The aim and objective at this stage were to define an overarching research question(s). According to Tranfield et al. (2003), the relevance of a study is partly dependent on the research question. A well-formulated and clear research question determines the eligibility for inclusion and exclusion of relevant and irrelevant studies. This study underwent a series of iterations to formulate the research question below by the application of the CIMO (Context, Intervention, Mechanism, and Outcome) logic:

"What growth factors impact the agro-processing sector of Ghana for economic growth and structural transformation?"

Using the CIMO logic: The CIMO logic applies an analytical framework to the research question. According to CIMO, in a specific context (C), an intervention (I) is initiated to generate mechanisms (M) to deliver expected outcomes (O) (Pilbeam et al., 2012; Denyer \& Tranfield, 2009; Nurmala et al., 2017)). In this study, the context is developing countries (in this case, Ghana), the Intervention (I) is growth factors, the mechanism (M) is agroprocessing/manufacturing, and the Outcome $(\mathrm{O})$ is sustainable economic and structural transformation. Below is how the CIMO logic fits the RQ.
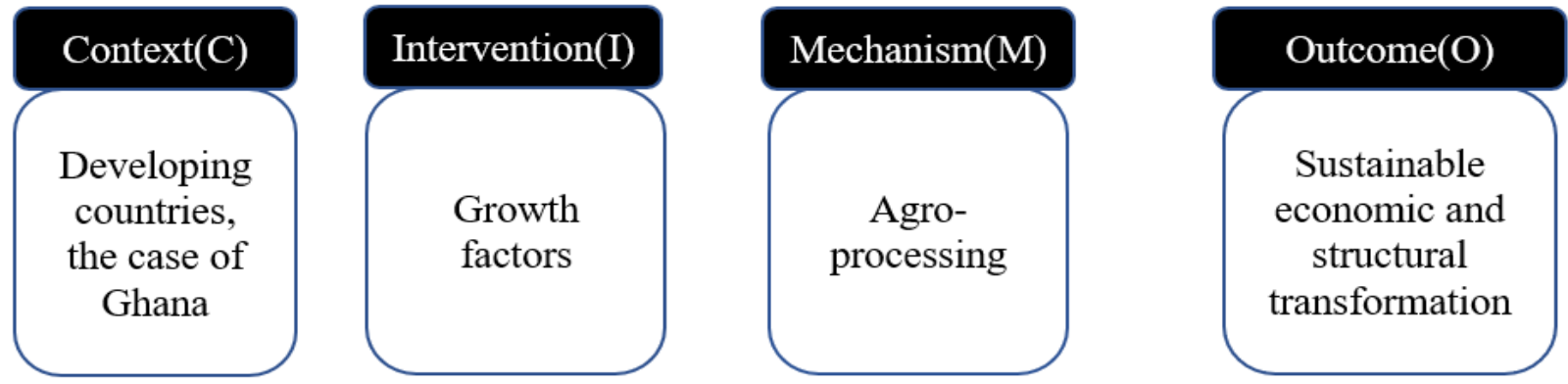

Figure 2: Application of CIMO Logic on the research question

Stage Two - Locating and Selecting Relevant Studies

At this stage, the strategy to search and retrieve relevant data was developed involving: (1) The selection and utilization of databases

(2) Formulation of search strings

(3) Establishment and application of inclusion and exclusion criteria

(4) Determination of eligibility of relevant studies.

The study used a blending effect of snowball and building-block approaches, a complementary approach to the literature search. With the snowball effect, the study used focal articles and searches backward for references in that article while the building-block approach involved the iterative interrogation (queries) of databases using a search string formulated by the combination of keywords and synonyms, AND and OR Boolean search connectors and modifiers, and search delimiters (as per databases used below) to identify relevant studies on the research question (Goodman et al., 2014). The 'OR' connector broadened and 'AND' connector narrowed the scope of the search respectively (p.324). Boolean search modifiers, such as '*' and '?', were used to retrieve likely variations of search phrases or words. The study conducted six searches using carefully formulated search strings based on keywords in RQ in the databases below:

- University of Maryland Global Campus (UMGC) OneSearch

- $\quad$ Business Source Complete (BSC)

- $\quad$ ABI/INFORM (ABI)

For ensuring a comprehensive, exhaustive, and aggregative literature search, the study also utilized the google scholar (GS) search engine to gather other study-relevant literature (Higgins \& Green, 2011). The study applied inclusion and exclusion criteria to the database search results to assess the relevance of each piece of retrieved literature to the research objectives (Nurmala et al., 2017), as summarized in Table 1 below. The Preferred Reporting Items for Systematic Review and Meta-Analyses (PRISMA) chart (seen in figure 2 below), was also used to provide a schematic depiction of the screening, application of inclusion and exclusion criteria to the search, screening, determination of eligibility, and selection of literature included and synthesized for the study (Moher et al., 2009). Table 2 also shows the search strings, databases used, and search results. A total of 9202 articles emerged from 6 searches (UMGC OneSearch $=48, \mathrm{BSC}=8564, \mathrm{ABI}=35, \mathrm{GS}=555$ ), with the addition of 31 articles 
from other sources including the snowball effect. Removal of duplicates, application of the inclusion and exclusion criteria, and search limiters resulted in 107 articles. The 107 articles were further assessment of the 107 articles for scope, detail, and rigor to yield 44 articles that were eligible for TAPUPAS (Transparency, Accuracy, Purposivity, Utility, Propriety, Accessibility, Specificity) critical appraisal (approach discussed in stage four below) (Porter, 2007). The critical appraisal of 44 articles yielded a selection of 31 relevant articles for thematic synthesis and extraction of relevant evidence to address the research question. * is used to indicate each of the 31 included articles in the references.

Table 1

Inclusion and Exclusion Criteria

\begin{tabular}{|c|c|}
\hline Inclusion criteria & Exclusion criteria \\
\hline Peer-reviewed articles/journals & Non-peer reviewed articles \\
\hline Year of Publication 2000-2021 & Articles not published from $2000-2021$ \\
\hline Articles are written in English & Articles not written in English \\
\hline $\begin{array}{l}\text { Key terms from RQ and/or its synonyms found in } \\
\text { abstract }\end{array}$ & $\begin{array}{c}\text { Key terms in RQ and/or its synonyms not found in } \\
\text { abstract }\end{array}$ \\
\hline
\end{tabular}
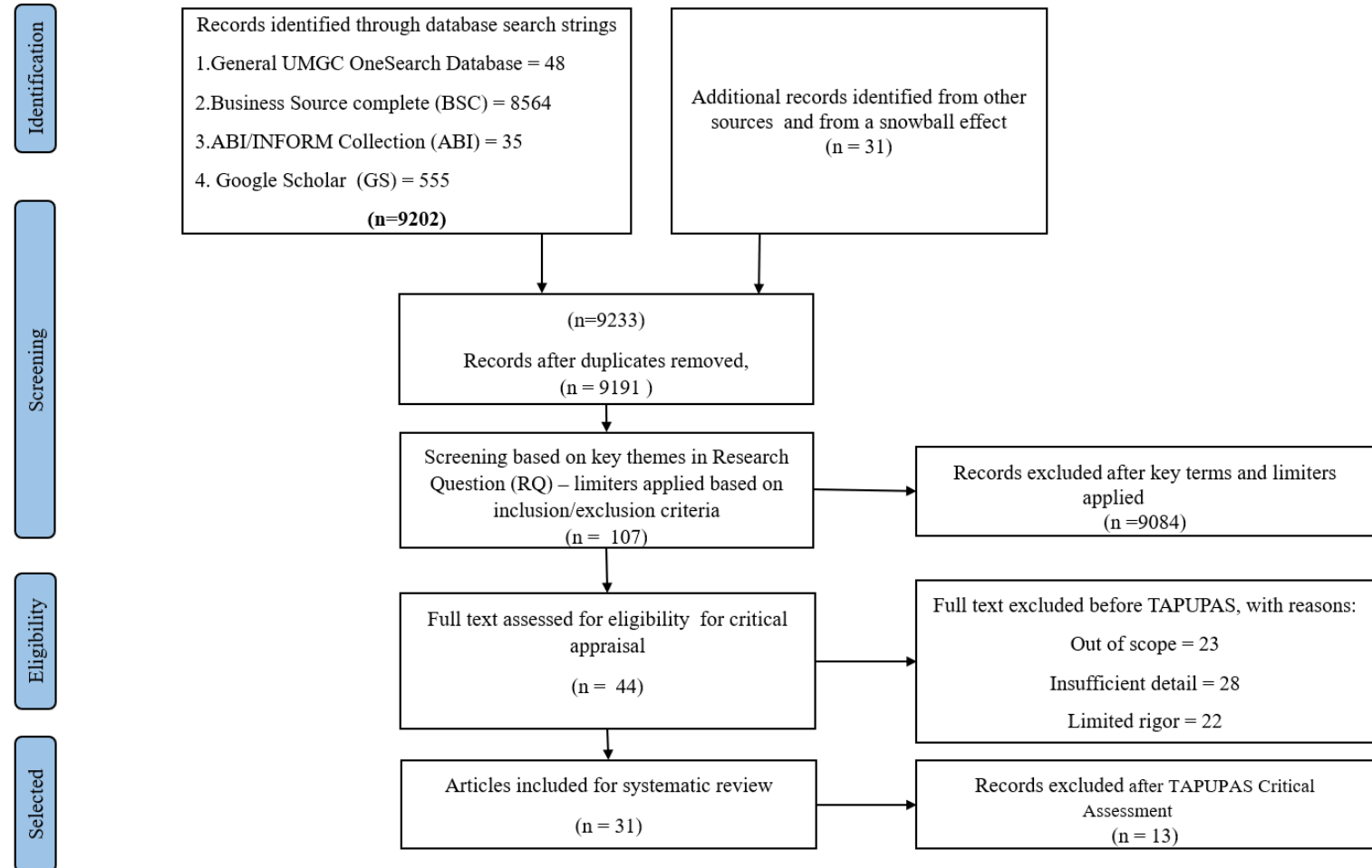

Figure 2: Search process and results flow chart. Adapted from "The Preferred Reporting Items for Systematic Review and Meta-Analyses: The PRISMA Statement” by Moher et al., (2009) 
Table 2

Search results from database searches

\begin{tabular}{|c|c|c|c|}
\hline \# & Search string & Database & Search results \\
\hline \multirow[t]{9}{*}{1} & econom* n5 (grow* OR develop*) AND (factor* OR barrier* OR facilitat* & 1. UMGC & 48 \\
\hline & OR challenge* OR problem* OR issue*) AND (agro-based* OR & database & 84 \\
\hline & "agricultur* processing" OR "food process*”) AND ( manufactur* OR & 2. GS & \\
\hline & industr* OR process*) AND ("developing countr*" OR "third-world countr" & & \\
\hline & OR "third world countr*" OR "developing countr*" OR "poor countr* OR " & & \\
\hline & african countr*") AND ("developed countr*" OR "advanced countr*" OR & & \\
\hline & USA OR "United States" OR "United states of America" OR Japan OR & & \\
\hline & China OR Europe OR "European Countr*" OR germany OR "asian countr*" & & \\
\hline & OR "western countr*") & & \\
\hline 2 & $\begin{array}{l}\text { ("agro processing" OR "agro-based manufact*") OR ("manufacturing value } \\
\text { add") }\end{array}$ & $\mathrm{BSC}$ & 1293 \\
\hline 3 & noft(agro-based industry) AND noft(development and economic growth) & $\mathrm{ABI}$ & $\begin{array}{l}23 \text { after } \\
\text { duplicates } \\
\text { were } \\
\text { removed. }\end{array}$ \\
\hline 4 & $\begin{array}{l}\text { noft(agro-based industry or agro-based manufacturing) AND noft(economic } \\
\text { development and growth or gdp growth) }\end{array}$ & ABI & 12 \\
\hline 5 & $\begin{array}{l}\text { (agro-based or agricultur*) and ("manufacturing or structural transformation } \\
\text { or industri*) AND econom* n5 (grow* OR develop*) }\end{array}$ & $\begin{array}{l}\text { 1. } \mathrm{BSC} \text {; } \\
\text { 2. GS }\end{array}$ & $\begin{array}{l}7271 \quad \text { (with } \\
\text { duplicates) } \\
471\end{array}$ \\
\hline 6 & ("agro processing") AND ("manufacturing) & $\mathrm{BSC}$ & 32 \\
\hline
\end{tabular}

Stage Three - Data Extraction

Data collection is an important step in the systematic review process. Essential text and data from the selected articles studies were systematically obtained explicitly and consistently according to a defined data extraction strategy and conduct of research design (Cruzes \& Dybå, 2011; Pollock \& Berge, 2018). This study adopted a modified extraction template from Cruzes \& Dybå (2011) (see appendix A for additional detail) and it included the following headings: (1) title of the study, (2) the author and year of publication (3) types of factors impacting agro-processing and/or link to economic growth and structural transformation, (4) study aim and objective, (5) study design approach, (6) main/key findings, and (7) implication to management practice.

Stage Four - Quality Assessment of Included Studies - A Critical Appraisal

Assessment of the methodological quality of the included studies is a key stage of the SR methodology. It involves critical appraisal and judgment to establish potential risks of bias within each eligible study. Pawson et al (2003), in Kneafsey (2007), asserted that the TAPUPAS framework provides a generic standard to evaluate the quality of evidence derived from practitioner research; policy; user and organizational sources of knowledge and addresses the transparency, accuracy, purposivity, utility, propriety, and accessibility of the evidence. Each article eligible for critical appraisal was rated for quality per each of the 7 dimensions of the TAPUPAS framework. Each scored either Low (score=1), Medium (Score =2), or High $($ Score=3) on Transparency, Accuracy, Purposivity, Utility, Propriety, Accessibility, and Specificity. A rating of Medium (score=2) across all 7 TAPUPAS dimensions results in an average score of 14 . For this study, an article is rated poor quality and excluded when it received a total score below the average of 14 . As evidenced in figure 2 above, 13 articles were considered poor quality following the TAPUPAS critical appraisal, scoring below the average of 14.31 articles were considered average or aboveaverage quality and included for the thematic synthesis of relevant evidence to address the RQ. Appendix B shows the critical appraisal results of the 31 included articles.

Stage Five - Analysis and synthesis

All SRs should involve the analysis and synthesis of the evidence found from the included studies (Pollock \& Berge, 2018). Synthesis involves summarizing the results in tables or producing a narrative summary. Synthesis of relevant and quality evidence is crucial to evidence-based management decision-making. This is the stage where meaning was generated from data gathered and aggregated from the included studies to address the RQ of this study. SR methodology advocates for various methods of qualitative research synthesis including but not limited to thematic, mixed knowledge, meta-ethnography, and 'meta synthesis', and mixed-method synthesis approaches (Gough et al., 2012; Thomas \& Harden, 2008). According to Thomas \& Harden (2008) in Cruzes \& Dybå (2011), thematic synthesis draws on the principle of thematic analysis identifying recurring themes or issues in the primary studies, analyzing these themes, and concludes in systematic reviews. This study employed the thematic synthesis approach to evidence extraction from 31 included articles to address the research question through identification, analysis, and reporting of patterns (themes) within the available evidence. Hence, the reason why thematic coding was relevant. 
This study deployed three levels of coding: (1) the free line-by-line coding of the findings and conclusions from included studies; (2) the organization of the resulting 'free codes' into related areas to develop 'descriptive' themes; (3) and the generating 'analytical' themes (Gough et al., 2012; Thomas \& Harden, 2008).

Step one - Coding included studies for text: ATLAS.ti software version 9.1.6.0 was used to code studies included in this study. The line-by-line coding of the findings and conclusions from included studies resulted in 35 codewords (see Appendix $C$ for detail). Table 3 shows the codewords and their frequency of relatability in the different included studies. ATLAS.ti software was used to extract the hierarchical representation of each codeword and any associated quotation(s) from some of the articles included in the study (Appendix D has extra detail).

Table 3

Shows The 35 Code Words and their frequencies of Appearance during the Coding Process

\begin{tabular}{|c|c|c|}
\hline \# & Codewords & $\begin{array}{c}\text { Frequency of relatability in included } \\
\text { articles }\end{array}$ \\
\hline 1 & Agricultural development and growth on manufacturing & 5 \\
\hline 2 & Agro-business access to capital & 10 \\
\hline 3 & Agro-processing or agro-based manufacturing employment & 28 \\
\hline 4 & Agro-processing or agro-manufacturing causes GDP growth & 8 \\
\hline 5 & An environment that fosters entrepreneurship and innovation & 4 \\
\hline 6 & collaboration and coordination between agro-businesses & 3 \\
\hline 7 & $\begin{array}{l}\text { A competitive marketplace facilitates agricultural growth and } \\
\text { manufacturing }\end{array}$ & 22 \\
\hline 8 & Enabling resources and capability growth of agro-based industry & 2 \\
\hline 9 & Endogenous factors & 2 \\
\hline 10 & Exogenous factors (e.g., IMF, WTO, etc.) & 4 \\
\hline 11 & Favorable economic policies, institutions, and structures & 28 \\
\hline 12 & financial structure, tools, and alternatives & 5 \\
\hline 13 & Foreign direct investment (FDI) & 6 \\
\hline 14 & Geography impacts agricultural production and industrialization & 4 \\
\hline 15 & Impact of the formal nature of agro-processing value chain & 1 \\
\hline 16 & Increased and demand-driven exports of manufactured goods & 9 \\
\hline 17 & innovation and technology capability & 9 \\
\hline 18 & Institutions for Research \& Development & 1 \\
\hline 19 & interruption of energy supply to firms for continuous production & 3 \\
\hline 20 & Knowledge development & 8 \\
\hline 21 & Lack of a safe and social environment & 3 \\
\hline 22 & lack of process and structure in managing an agro-enterprise & 6 \\
\hline 23 & Lack of technological or technical advancement & 25 \\
\hline 24 & Land availability and impact on agricultural production & 4 \\
\hline 25 & Management efficiency & 9 \\
\hline 26 & $\begin{array}{c}\text { Merger and cooperation of small and medium scale agro-based } \\
\text { enterprises }\end{array}$ & 2 \\
\hline 27 & Natural disasters and unexpected weather circumstances & 1 \\
\hline 28 & $\begin{array}{l}\text { open, uneven market competition, and opportunities for } \\
\text { international trade }\end{array}$ & 39 \\
\hline 29 & productive labor force with the technical know-how & 22 \\
\hline 30 & $\begin{array}{l}\text { the proximity of raw materials can maximize the productivity of } \\
\text { firms }\end{array}$ & 5 \\
\hline 31 & Quality products, packaging, and branding & 4 \\
\hline 32 & Reducing agricultural taxation for trade expansion & 9 \\
\hline 33 & Skill development and continuous training of labor force & 11 \\
\hline 34 & Structural transformations to GDP growth & 10 \\
\hline 35 & Supply chain constraints such as poor road infrastructure & 8 \\
\hline
\end{tabular}

Step Two - Develop descriptive themes: In this step, primary code words were grouped into related areas to develop 10 descriptive themes (see example in Appendix E). The descriptive themes are the following:

(1) Agricultural production impacts manufacturing growth,

(2) Agro-processing increases employment and reduces poverty,

(3) Competitive marketplace facilitates agricultural growth and manufacturing,

(4) Endogenous factors impacting agro-processing or agro-manufacturing,

(5) Exogenous factors impacting agro-processing/manufacturing,

(6) Exports of agro-processed or manufactured goods is a growth factor, 
(7) Favorable policies requirements help businesses to thrive, grow and expand,

(8) Merger and cooperation of small and medium scale boost agro-industrialization,

(9) Smart Government funding is instrumental to boosting agro-processing, and

(10) Social and structural transformation is evidence of economic growth and

Step 3 - Developing analytical themes: At this step, seven (7) analytical themes were developed from the 10 descriptive themes above. Each analytical theme was linked back to the primary codes, as shown with theme \# 3 in the Appendix F example. Appendix G also tabulates the analysis of the formation of the analytical themes from primary codes and descriptive themes. Each analytical theme is analyzed and discussed in the "Findings and Discussions" section below.

Stage Six - Interpretation and Reporting

At this stage, the study presents results from the SR. A good systematic review should make it easier for practitioners to understand by providing specific exemplars and a trail of evidence to support conclusions (Tranfield et al., 2003). The analytical themes were summarized and discussed in the 'Synthesis \& Discussion' section for the benefit of management practitioners, according to how they addressed the overarching research question in this study (Pollock \& Berge, 2018).

\subsection{Findings/Results}

This study, again, identifies and examines growth factors that impact the agro-processing industry, a subset of the manufacturing sector of Ghana, towards sustainable economic and structural transformation. The thematic synthesis approach to evidence extraction was used to derive seven (7) analytical themes that directly addressed the RQ below:

What are the growth factors that impact the agro-processing industry for economic and structural transformation?

The seven analytical themes address the RQ. Theme 1 addressed the 'growth factors' aspect of the RQ, and Themes 2-7 affirmed the link towards economic growth and structural transformation (all themes are discussed in detail in the next section). The themes are also a direct reflection of the conceptual framework and highlight the impact of endogenous and exogenous factors on agro-processing-driven industrialization, coupled with the requirements towards Ghana's take-off to economic maturity. Twenty (20) growth factors were discovered. Of the 20 , technology and innovation capability, favorable policies for agro-processing, and a competitive and open market growth factor recorded the highest percentages of 42, 45, and 55 respectively, as it relates to the common themes from the 31 different articles that were included, which stresses their weight and impact on agro-processing and manufacturing value-add (MVA) in general.

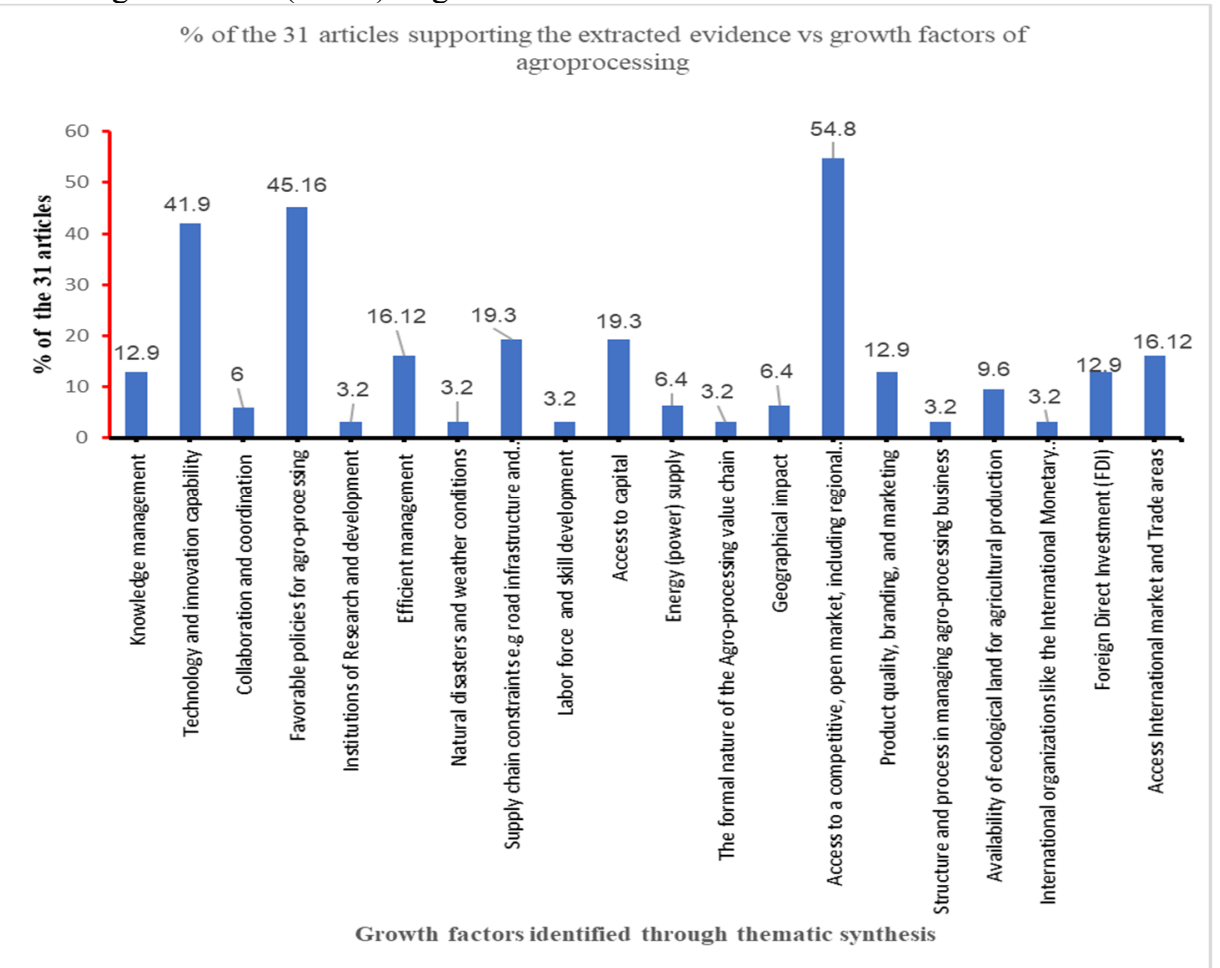

Figure 3: A plot of growth factors impacting the agro-processing sector versus the percentage of common themes from the 31 articles that were included. 


\subsection{Synthesis \& Discussion}

This study is a systematic review, an evidence-based research approach, to examine the factors that influence the agro-processing and manufacturing value add towards economic growth and development of Ghana. Evidencebased management (EBMgt) utilizes the best available evidence to make management decisions. Accelerating economic development in Ghana is a matter of practice. However, leaders in Ghana and other developing countries require the best, quality, credible and available evidence to inform the required economic growth and development decision-making, which helps to bridge the gap between research and practice in Ghana. The RQ for this study was:

What are the growth factors that impact the agro-processing sector of Ghana for economic and structural transformation?

The thematic synthesis resulted in 35 initial code words, which were further grouped based on related concepts into 10 'descriptive' themes. The seven (7) analytical themes that were developed from the 10 descriptive themes are discussed as follows.

Theme 1: The agro-processing or agro-manufacturing industry is impacted by endogenous and exogenous growth factors.

This study categorized the growth factors that have a potential impact on the agro-processing industry in Ghana into 17 endogenous and 3 exogenous concerns. Endogenous factors are internal to a system, influencing the system from within (Shifa, 2015). The influence of exogenous factors, on the other hand, are external to the system. The endogenous factors are the following:

(1) Knowledge management

(2) Technology and innovation capability

(3) Collaboration and coordination

(4) Favorable policies for agro-processing

(5) Institutions of research and development

(6) Efficient management

(7) Natural disasters and weather conditions impacting the ecological landscape

(8) Supply chain constraints e.g., road infrastructure and technology utilization

(9) Labor force and skill development

(10) Access to capital

(11) Energy (power) supply

(12) The formal nature of the Agro-processing value chain

(13) Geographical impact

(14) Access to a competitive, open market, including regional free trade area

(15) Product quality, branding, and marketing

(16) Structure and process in managing the agro-processing business

(17) Availability of ecological land for agricultural production

The exogenous factors are also as follows:

(1) International organizations like the International Monetary Fund (IMF)

(2) Foreign Direct Investment (FDI)

(3) Access to international market and trade

Ghana, as an economic system, is faced with endogenous and exogenous growth factors that directly impact the agro-manufacturing ecosystem. Appendix $\mathrm{H}$ tabulates and compares Ghana with the advanced economies in terms of all the growth factors herein found. Knowledge management, as an example, could be achieved through research and development (R\&D), continuous human capital development and training, advising, enforcing context-based approaches to learning, and learning by doing techniques in agro-processing and manufacturing industries (Njuguna \& Wanjohi, 2021; Osei-Amponsah, 2020; Bjornlund et al., 2020; Thindisa \& Urban, 2018; Rae \& Josling, 2003; Tandoh-Offin, 2011). Promotion of effective knowledge management leads to organizational and technical efficiencies in especially small and medium scale agro-processing industries towards economic growth (Njuguna \& Wanjohi, 2021; Osei-Amponsah, 2020). Building technology and innovation capability is also a huge growth factor. Investments in technology and innovation hubs, especially when formulated on a bedrock of sound and favorable economic policies, promote entrepreneurship in the agro-processing sector and should be encouraged in developing countries like Ghana. Asare \& Essegbey (2016) affirmed the need to also commercialize technology development, innovation capability, and government investment towards agro-processing. There is also the added need to move away from only niche-specific and internet-based knowledge acquisition to a more formal and institutional capacity building founded on deliberate and effective technology utilization (OseiAmponsah, 2020).

Theme 2: Governments should focus on smart economic policies, regulations, and funding mechanism that accelerates agro-processing/manufacturing industrialization.

This study underscored and advocates the need for developing economies, like Ghana, to invest time and 
efforts in formulating policies that encourage entrepreneurship in the agro-processing or manufacturing industrial landscape. It asserts the need for policy experiments in the areas of economic, social, and structural transformation, not limited to road infrastructure, fostering agro-processing entrepreneurship, enabling financial structures and access to capital for agro-business, foreign direct investment (FDIs), local and international trade and marketing, technology innovations and capacity building efforts, just to mention a few, to drive accelerated growth in the agro-processing sector. This assertion is echoed by Newfarmer et al. (2018), who affirmed the need for increased formulation of liberal policies and regulations, for example, that creates the enabling environment for businesses to thrive and fosters agricultural production, technological innovation, financial sector regulations, and sustained manufacturing value-add.

Theme 3: Merger and cooperation of small and medium scale industries expands the agro-processing sector and accelerates industrialization

Small and medium scales firms often face a range of issues from access to capital to being able to afford technologies for enhanced productivity, which hinders their growth and access to local and international markets. For rapid industrialization, merger and cooperation are encouraged. Small agro-processing companies can merge and cooperate with other entities to allow rapid scaling. Derbile et al. (2012) confirmed that issues, not limited to access to capital and credit, technology, lack of marketing innovation, and simple ignorance, hinder the growth and scaling of small agro-processing industries. In India, for example, the work of Bedi (2010) confirmed that merger and acquisition deals in the manufacturing sector increased by 272 percent, allowing sectoral growth and increased competition in the global market.

Cooperatives could be used as a vehicle for industrialization while finding opportunities to correct structural imbalances while reducing or eliminating differences in sectors and regions (Katundu, 2018). The vehicle of cooperation could take the form of various regional policy arrangements between countries that fundamentally bolster integrated trade and production towards industrial and structural transformation of local economies (KozulWright \& Fortunato, 2019). As a result, regional value chains can be improved and structural development centers can be built to support competitiveness among domestic firms in member countries. It is recommended for developing countries, like Ghana, to adopt strategic policy measures both at the domestic and sub-Saharan regional levels. Developed countries are aligned to making arrangements for Free Trade policies (Feinberg, 2003), which Ghana can replicate and continuously encourage. The most recent and useful strategic policy arrangement that Ghana part took in is joining the African Continental Free Trade Area (AfCFTA). This arrangement continues to afford industries, not limited to agro-processing firms in Ghana, the regional opportunity to trade in goods and services with 31 other member countries.

Additionally, small and medium-scale agro-processing firms could garner several benefits upon joining cooperatives. Cooperatives could be a platform for knowledge and experience sharing, coupled with access to various forms of training programs and facilities (Boodhoo et al., 2010). Some of the training benefits may include but are not limited to improving work skills and know-how, improving product quality and marketing, new product development, and business management It is also an opportunity to improve and increase the competitiveness of firms.

Theme 4: Increased agricultural productivity causes continuous growth in agro-processing/manufacturing

Sustained agricultural productivity remains an asset to agro-processing/manufacturing. This study found that agricultural production has a significant and positive impact on manufacturing growth (Shifa, 2015). Continuous production of raw materials leads to continuous supply input to agro-manufacturing. A shortage of raw materials due to low agriculture total productivity has a direct and consequential impact on agro-processing. A developing economy, like Ghana, needs to focus on productive agriculture production that ensures the continuous provision of raw material to the agro-processing sector towards economic growth. However, in the wake of increased agromanufacturing and industrialization, leaders of Ghana need to be mindful of the possible shift of labor from agriculture to production sector manufacturing, which can hinder economic growth. Ghana will need to find the balance, an assertion confirmed by Johnston \& Mellor (1961) in the work on "The Role of Agriculture in Economic Development."

Other studies also confirm why scarcity of agricultural raw materials makes the agro-processing sector suffer. Chavas (2008) stated that, amidst diminishing marginal productivity, obtaining higher outputs becomes increasingly difficult. This implies that significant effort is required to ensure increased raw materials for the agroprocessing or manufacturing sector. Despite the assertion that this sector is marked with low margins, seasonality, variability, and perishability (Chengappa, 2004; Asokan \& Singh, 2003) of raw materials, Asokan \& Singh (2003) suggested the need for the agro-processing firms to properly understand the supply chain dynamics to prevent any loss in business. Agro-processing firms in Ghana can, therefore, purchase or make strategic arrangements to access raw materials on time and in the right quantity to ensure business assurance, continuity, and customer satisfaction, while maintaining increased competitiveness on both local and international markets.

Theme 5: Increased and continuous access to international trading markets and demand-driven exports of agromanufactured boosts economic growth 
This study asserts that access to the international market and trading opportunities for agro-manufactured products is a booster of economic growth by creating employment opportunities. Awad (2019) confirmed that a nation's openness to the global trade market lowers the unemployment rate of the country. Openness to the international market is an economic step for Ghana. Advanced economies like the United States are often open to open markets. Open and wider markets serve to catalyze wider trade agreements, support domestic market-oriented reformers, strengthen strategic partnerships, etc. (Huang \& Xiong, 2018).

Theme 6: Enhancement of local value chain mechanisms through policy, efficient management, branding, and packaging of agro-processed/manufactured products can boost economic growth.

This study shows that the growth of the agro-processing sector is hinged on policies that encourage technological innovations and utilization in the agro-processing value chain. Small and medium-scale agroenterprises are encouraged to establish efficient structures and processes towards efficient business management. This ultimately feeds into better marketing, rebranding, and packaging agro-manufactured products - a competitive presence in the local and international markets. The competitive presence and sales of manufactured products both on the local, regional, and other international markets is a driver of economic (GDP) growth, reducing unemployment and poverty rates (Awad, 2019; Ntara, 2016).

Theme 7: Access to foreign direct investment and government funding to the agro-industrial sector is an economic development accelerator

Access to foreign direct investments (FDIs) is an economic growth factor and could sometimes be more effective than trade by generating sales of products from the agro-industrial complex. This study also confirmed that carefully leveraging FDI and government funding can propel rapid agro-processing industrialization. FDI can be used to afford the training and development of technological innovations towards increased manufacturing value-add and enhanced marketing capacity that allows for industrial scaling and facilitation of global market and product competition. FDI is an enabler of the transition to market and economic growth (Popescu, 2014). Abor et al (2008) also confirmed that FDI could be used to sponsor an export performance of most products, not limited to products from the agro-processing sector to the international market for an accelerated marketing presence and competitiveness.

\subsection{Conclusion \& Recommendations}

This evidence-based research sought to bridge the gap between research and practice, help leaders I Ghana and other developing countries to make decisions that solves the challenges faced with the agro-processing using the best available, quality, credible, and synthesized evidence. The problem is that the agro-processing sector of Ghana is still weak today despite Ghana being known as a haven for agricultural raw materials. The systematic review methodology used to explicitly examine the growth factors that impact the agro-processing sector of Ghana for economic growth and development. Evidence from 31 included/selected articles were aggregated and analyzed through a 3-step thematic synthesis approach to yield seven (7) analytical themes (discussed above). The analytical themes directly bridge the gap between research and practice to allow leaders in Ghana and all interested stakeholders to make decisions on how to leverage the agro-processing sector for economic growth and structural transformation of the nation, possible by understanding all the possible growth factors. The following are therefore recommended for the government of Ghana and other developing countries in Sub-Saharan Africa and around the world:

1. Understand and work out an implementation plan on all the endogenous and exogenous growth factors impacting the agro-processing or agro-manufacturing industry. Endogenous factors include but are not limited to knowledge management, technology and innovation capability, favorable economic policies, etc. Exogenous factors include the influence of external organizations like IMF, Foreign Direct Investments (FDIs), International trade and markets, etc.

2. Deliberate focus on smart economic policies, regulations, and funding mechanism that accelerates agroprocessing/manufacturing industrialization.

3. Create a business environment that encourages merger and cooperation of small and medium scale industries towards an expanded and accelerated industrialization

4. Ensure a careful increase in agricultural productivity to continuously provide agricultural raw materials as an input to the sustainable growth of agro-processing/manufacturing. However, as the country rapidly industrializes, there is a need to be mindful of labor shifts from the agriculture sector to the manufacturing industrial complex.

5. Ensure increased, continuous, and facilitated access to international trading markets and demand-driven exports of agro-manufactured as a boost for economic growth.

6. Enhancement of local value chain mechanisms through policy, efficient management, branding, and packaging of agro-processed/manufactured products can boost economic growth.

7. Encourage controlled access and utilization of foreign direct investments and government funding to grow and cause structural transformation of the agro-industrial complex. 


\subsection{Study Limitations}

This study used an academic constraint of seven (7) weeks to conceptualize and complete the systematic review and report findings. It also used UMGC OneSearch, Business Source Complete, ABI/INFORM, and Google Scholar databases such that, additional databases could have added to the comprehensiveness of the search for other credible scholarships. Additionally, the selection and inclusion of 31 articles, thematic synthesis, and evidence extraction from the articles were conducted by only the researcher. Additional time and third-party reviews may have allowed an extra layer of scrutiny of the analysis and findings coupled with reducing any possible biases.

\subsection{Implications for Practice}

This study is a resource for management practitioners in Ghana, government leaders, and economic development consultants to understand the growth factors that can either hinder or facilitate the utilization of agroprocessing/manufacturing as a means to economic growth and structural transformation. The growth of the agroprocessing sector directly increases manufacturing value-add and grows the GDP of the country. Also, the expansion of the agro-processing sector leads to industrialization, typically evident in structural transformation. This evidence-based research provides credible and carefully synthesized evidence to help decision-making on why the agro-processing sector of Ghana is still weak today, despite its independence in 1957.

\subsection{Future Research}

This study is a foundational work on the factors impacting agro-processing for economic growth and development. Recommended future studies are to look at each endogenous and exogenous factor and perform a country-specific or general impact analysis.

\section{References}

“*” Denotes articles used in the systematic review

*Abid Sultan, S., \& Deepak, J. (2017). Competitiveness of agro-processing firms: productivity approach.

Abor, J., Adjasi, C. K. D., \& Hayford, M. C. (2008). How does foreign direct investment affect the export decisions of firms in Ghana? African Development Review, 20(3), 446-465. https://doi.org/10.1111/j.14678268.2008.00193.x

Abor, J., \& Quartey, P. (2010). Issues in SME development in Ghana and South Africa. International Research Journal of Finance and Economics, 39(February), 218-228.

*Adaku, E., Amoatey, C. T., Nornyibey, I., Famiyeh, S., Asante-Darko, D., \& Gingue, N. (2018). Delays in new product introduction: Experiences of a food processing company in a developing economy. Journal of Manufacturing Technology Management, 29(5), 811-828. https://doi.org/10.1108/JMTM-09-2017-0190

Adarkwah, J., \& Nyanzu, F. (2016). Effect of Power Supply on the performance of Small and Medium Size Enterprises: A comparative analysis between SMEs in Tema and the Northern Part of Ghana. Journal of Economic Literature, 74196, 1-18.

*Ahmad, A. Y. (2020). Unlocking the potentials of Micro and Small Enterprises (MSEs) in building local technological capabilities in agro-processing industry. Innovation and Development. https://doi.org/10.1080/2157930X.2020.1836460

*Ahmed, M. D. S., Ahmed, M. D., \& Haider, M. Z. (2014). A Nonparametric Estimation of Total Factor Productivity Growth of Manufacturing Firms. New Zealand Journal of Applied Business Research (NZJABR), 12(1), 49-66. http://search.ebscohost.com/login.aspx?direct=true\&db=bth\&AN=100821828\&site=ehostlive

Asare, R., \& Essegbey, G. O. (2016). Funding of Agricultural Research and Development in Ghana: The Case of Council for Scientific and Industrial Research (CSIR). Technology and Investment, 07(02), 40-50. https://doi.org/10.4236/ti.2016.72006

Asokan, S. R., \& Singh, G. (2003). Role and constraints of contract farming in agro-processing industry. Indian Journal of Agricultural Economics, 58(3), 566-576. https://doi.org/10.22004/AG.ECON.297972

*Atayi, A. V., Adekunle, O. S., Ojo, B. A., \& Nkire, N. (2021). Agriculture, Manufacturing and Economic Growth in Nigeria. International Journal of Multidisciplinary Research and Analysis, 04(03), 337-347. https://doi.org/10.47191/ijmra/v4-i3-18

Awad, A. (2019). Economic Globalisation and Youth Unemployment-Evidence from African countries. International Economic Journal, 33(2), 252-269. https://doi.org/10.1080/10168737.2019.1604787

Bedi, H. S. (2010). MERGER \& ACQUISITION IN INDIA : An Analytical Study by Lovely School of Business Lovely Professional University MERGER \& ACQUISITION IN INDIA : An Analytical Study. SSRN.

*Bjornlund, V., Bjornlund, H., \& Van Rooyen, A. F. (2020). Why agricultural production in sub-Saharan Africa remains low compared to the rest of the world-a historical perspective. International Journal of Water Resources Development, sup1, 1-34. https://doi.org/10.1080/07900627.2020.1739512 
Boodhoo, K., Goburdhun, D., \& Ruggoo, A. (2010). An Appraisal of The Small-Scale Agroprocessing Sector in Rodrigues - Part 2: Product Marketing, Training Programmes and Awareness of Support Services. University of Mauritius Research Journal, 16(1), 58-83.

Boonekamp, G. M. ., Costongs, C., Logghe, K. L. ., \& Venne Van Der, M. M. E. J. (1998). International Networking:A healthy vehicle for research? SpringerBriefs in History of Science and Technology, 27-42. https://doi.org/10.1007/978-3-030-59188-5_3

Brako Ntiamoah, E., Li, D., \& Kwamega, M. (2016). Impact of Government and Other Institutions' Support on Performance of Small and Medium Enterprises in the Agribusiness Sector in Ghana. American Journal of Industrial and Business Management, 06(05), 558-567. https://doi.org/10.4236/ajibm.2016.65052

*Breisinger, C., Diao, X., \& Thurlow, J. (2009). Modeling growth options and structural change to reach middle income country status: The case of Ghana. Economic Modelling, 26(2), 514-525. https://doi.org/10.1016/j.econmod.2008.10.007

Briner, R. B., Denyer, D., \& Rousseau, D. M. (2009). Evidence-based management: Concept cleanup time? Academy of Management Perspectives. https://doi.org/10.5465/AMP.2009.45590138

Brinkman, R. (1995). Economic Growth versus Economic Development: Toward a Conceptual Clarification. Journal of Economic Issues, 29(4), 1171-1188. https://doi.org/10.1080/00213624.1995.11505746

*Caselli, F., \& Coleman II, W. J. (2001). The U.S. Structural Transformation and Regional Convergence: A Reinterpretation. Journal of Multicultural Counseling and Development, 29, 147-158.

Census and Economic Information Center. (n.d.). United States US: GDP: \% of Manufacturing: Food, Beverages and Tobacco.https://www.ceicdata.com/en/united-states/gross-domestic-product-share-of-gdp/us-gdp--ofmanufacturing-food-beverages-and-tobacco

Chavas, J. P. (2008). On the economics of agricultural production. Australian Journal of Agricultural and Resource Economics, 52(4), 365-380. https://doi.org/10.1111/j.1467-8489.2008.00442.x

Chemura, A., Schauberger, B., \& Gornott, C. (2020). Impacts of climate change on agro-climatic suitability of major food crops in Ghana. PLoS ONE, 15(6), 1-21. https://doi.org/10.1371/journal.pone.0229881

Chengappa, P. G. (2004). Emerging trends in agro-processing in India. Indian Journal of Agricultural Economics, 59(1), 55-74. https://doi.org/10.22004/ag.econ.204356

Coman, K., Bogart, E. L., Ely, R. T., \& Gay, E. F. (2012). Stages of Economic Development . -Discussion. 8, 1 11.

Cortright, J. (2001). New Growth Theory, Technology and Learning: A Practitioner's Guide New Growth Theory, Technology and Learning A Practitioners Guide Joseph Cortright. Development, 4, 40.

Cruzes, D. S., \& Dybå, T. (2011). Recommended steps for thematic synthesis in software engineering. International Symposium on Empirical Software Engineering and Measurement, October, 275-284. https://doi.org/10.1109/esem.2011.36

*Dao, N. T. (2016). From agriculture to manufacturing: How does geography matter? In Cliometrica (Vol. 10, Issue 3). Springer Berlin Heidelberg. https://doi.org/10.1007/s11698-015-0132-3

*De Vries, G., Timmer, M., \& de Vries, K. (2015). Structural Transformation in Africa: Static Gains, Dynamic Losses. Journal of Development Studies, 51(6), 674-688. https://doi.org/10.1080/00220388.2014.997222

Derbile, E. ., Abubakari, A., \& Dinye, R. . (2012). Diagnosing challenges of small-scale industries Ghana: A case of agro-processing industries in Kassena-Nankana District. African Journal of Business Management, 6(47), 11648-11657. https://doi.org/10.5897/ajbm12.620

*Dorosh, P., \& Thurlow, J. (2018). Beyond Agriculture Versus Non-Agriculture: Decomposing Sectoral GrowthPoverty Linkages in Five African Countries. World Development, 109, 440-451. https://doi.org/10.1016/j.worlddev.2016.08.014

Dreher, A., \& Jensen, N. M. (2007). Independent actor or agent? An empirical analysis of the impact of U.S. interests on international monetary fund conditions. Journal of Law and Economics, 50(1), $105-124$. https://doi.org/10.1086/508311

Enete, A., \& Amusa, T. (2010). Challenges of Agricultural Adaptation to Climate Change in Nigeria: a Synthesis from the Literature. Field Actions Science Reports. The Journal of Field Actions, 4(Vol. 4), 0-11.

FAO. (2021). The impact of disasters and crises on agriculture and food security: 2021. In The impact of disasters and crises on agriculture and food security: 2021. https://doi.org/10.4060/cb3673en

Feinberg, R. E. (2003). The Political Economy of United States' Free Trade Arrangements. The World Economy, 26(7), 1019-1040. https://doi.org/10.1111/1467-9701.00561

Gabardo, F. A., Pereima, J. B., \& Einloft, P. (2017). The incorporation of structural change into growth theory: A historical appraisal. EconomiA, 18(3), 392-410. https://doi.org/10.1016/j.econ.2017.05.003

Gachora, J. W., Kibet, J., \& Musiega, D. (2014). Supply Chain Cost Reduction Impact on Performance of Small Scale Agricultural Enterprise. International Journal of Education and Reserch, 2(4), 377-390.

Goodman, J. S., Gary, M. S., \& Wood, R. E. (2014). Bibliographic search training for evidence-based management education: A review of relevant literatures. Academy of Management Learning and Education, 13(3), 322- 
353. https://doi.org/10.5465/amle.2013.0188

Gough, D., Thomas, J., \& Oliver, S. (2012). Clarifying differences between review designs $\backslash$ rand methods art:10.1186/2046-4053-1-28. Systematic Reviews, 1-9.

Gwynne, R. N. (2009). Modernization Theory. International Encyclopedia of Human Geography, 164-168. https://doi.org/10.1016/B978-008044910-4.00108-5

Hauschild, S., Licht, T., \& Wolfram, S. (2001). Creating a knowledge culture. Gale Academic Onefile, 48(1), 1820. https://doi.org/10.1108/00438029910246769

*Hawkes, C. (2005). The role of foreign direct investment in the nutrition transition. Public Health Nutrition, 8(4), 357-365. https://doi.org/10.1079/phn2004706

Huang, Y., \& Xiong, W. (2018). Geographic Distribution of Firm Productivity and Production : A “ Market Access " Approach. Working Paper.

Hunter, M. (2012). The stages of Economic Development From an Opportunity Perspective: Rostow Extended. Geopolitics, History, and International Relations, 4(2), 52-80.

Johnston, B. F., \& Mellor, J. W. (1961). The Role of Agriculture in Economic Development. The American Economic Review, 51(4), 566-593. http://www.jstor.org/stable/1812786

Johnson, P. N. T., Nketia, S., \& Quaye, W. (2015). Appraisal of Logistics Management Issues in the Agro-Food Industry Sector in Ghana. Journal of Agricultural Science, 7(3), 164-178. https://doi.org/10.5539/jas.v7n3p164

Kent, P., Keating, J., Bernhardt, J., Carroll, S., Hill, K., \& McBurney, H. (1999). Evidence-based practice. Australian Journal of Physiotherapy, 45(3), 167-171. https://doi.org/10.1016/S0004-9514(14)60347-0

*Klasen, S., Martínez-Zarzoso, I., Nowak-Lehmann, F., \& Bruckner, M. (2021). Does the designation of least developed country status promote exports? Journal of International Trade and Economic Development, 30(2), 157-177. https://doi.org/10.1080/09638199.2020.1831042

Kneafsey, R. (2007). A systematic review of nursing contributions to mobility rehabilitation: Examining the quality and content of the evidence. Journal of Clinical Nursing, 16(11C), 325-340. https://doi.org/10.1111/j.1365-2702.2007.02000.x

*Kodama, M. (2017). How strongly can industrial structural transformation affect GDP? Applied Economics, 49(36), 3623-3633. https://doi.org/10.1080/00036846.2016.1265075

Kuznets, S. (1973). Modern Economic Growth : Findings and Reflections. America n Economic Association, 63(3), $247-258$.

Kozul-Wright, R., \& Fortunato, P. (2019). Development Unchained: Trade and Industrialization in the Era of International Production. Global Policy, 10(1), 29-40. https://doi.org/10.1111/1758-5899.12601

Lang, V. (2020). The economics of the democratic deficit: The effect of IMF programs on inequality. Review of International Organizations, 599-623. https://doi.org/10.1007/s11558-020-09405-x

Leon, D., \& Augusto, L. (2000). Review and Evaluation of Publicly Funded Research and Development in AgroProcessing. Econstor: PIDS Discussion Paper Series, No. 2009.

Lepine, J., \& Wilcox-King, A. (2010). Editors' comments: Developing novel theoretical insight from reviews of existing theory and research. Academy of Management Review, 35(4), 506-509. https://doi.org/10.5465/AMR.2010.53502455

Lewis, A. W. (1954). Economic Development with unlimited supplies of labor.

Lin, L \& Hung-Hao, C. (2021). Does agro-processing adoption affect farm income and farm diversification? Empirical evidence from Taiwan. Journal of Agribusiness in Developing and Emerging Economies, 11(5), 567-577. https://doi-org.ezproxy.umgc.edu/10.1108/JADEE-07-2020-0157

Mankiw, G. N. (1995). The growth of nations. Nature, 474(7352), 448. https://doi.org/10.1038/474448a

*Manonmani, M. (2015). Impact of Global Economic Crisis on the Productivity Performance of Agro-based Industries in India: A Malmquist DEA Approach. Journal of Economic Policy and Research, 10(2), 130136. https://search.proquest.com/docview/1712757323? accountid=150292

Marsh, R. M. (2014). Modernization theory, then and now. Comparative Sociology, 13(3), 261-283. https://doi.org/10.1163/15691330-12341311

*Martin, W. (2019). Economic growth, convergence, and agricultural economics. Agricultural Economics (United Kingdom), 50(S1), 7-27. https://doi.org/10.1111/agec.12528

*Mashimba, S. H., \& Kühl, R. (2014). Performance of Micro and Small-Scale Enterprises (MSEs) in Tanzania: Growth Hazards of Fruit and Vegetables Processing Vendors. Journal of Applied Economics and Business Research JAEBR, 4(2), 120-133.

Mehetre, S. (2010). Agro-Processing Industries India: Growth, Status and Prospects. Journal Indonesian Agroindustries.

Melembe, T., Senyolo, G. M., \& Mmbengwa, V. M. (2021). Value added choice Factors influencing value-added agricultural choice within smallholder farming agribusinesses of Gauteng Province in South Africa. Journal of Agribusiness and Rural Development, 60(2), 183-191. https://doi.org/10.17306/j.jard.2021.01374 
Mensah, C. N., Dauda, L., Boamah, K. B., \& Salman, M. (2021). One district one factory policy of Ghana, a transition to a low-carbon habitable economy? Environment, Development and Sustainability, 23(1), 703721. https://doi.org/10.1007/s10668-020-00604-5

Moher, D., Liberati, A., Tetzlaff, J., Altman, D. G., Altman, D., Antes, G., Atkins, D., Barbour, V., Barrowman, N., Berlin, J. A., Clark, J., Clarke, M., Cook, D., D’Amico, R., Deeks, J. J., Devereaux, P. J., Dickersin, K., Egger, M., Ernst, E., ... Tugwell, P. (2009). Preferred reporting items for systematic reviews and metaanalyses: The PRISMA statement. PLoS Medicine, 6(7). https://doi.org/10.1371/journal.pmed.1000097

*Munyi, E. N. (2020). Africa's stalled structural transformation: the end of the flying geese? Review of African Political Economy, 47(165), 474-483. https://doi.org/10.1080/03056244.2020.1789855

*Ncube, P. (2018). The southern African poultry value chain: Corporate strategies, investments and agro-industrial policies. Development Southern Africa, 35(3), 369-387. https://doi.org/10.1080/0376835X.2018.1426446

Newfarmer, R., Page, J., \& Tarp, F. (2018). Industries without Smokestacks. Oxford ; University Press, 3, 103111.

Njuguna, A. W., \& Wanjohi, P. (2021). EFFECT OF BUSINESS PROCESS RE-ENGINEERING ON PERFORMANCE OF AGRO-PROCESSING FIRMS IN NAIROBI CITY COUNTY EFFECT OF BUSINESS PROCESS RE-ENGINEERING ON PERFORMANCE OF AGRO .... Journal of Business \& Change Management, October.

Ntara, C. (2016). African Trading Blocs and Economic Growth : a Critical Review of. International Journal of Developing and Emerging Economies Vol.4, 4(1), 1-21.

Nurmala, N., de Leeuw, S., \& Dullaert, W. (2017). Humanitarian-business partnerships in managing humanitarian logistics. Supply Chain Management, 22(1), 82-94. https://doi.org/10.1108/SCM-07-2016-0262

Nyamekye, A. P., Tian, Z., \& Cheng, F. (2021). Analysis on the Contribution of Agricultural Sector on the Economic Development of Ghana. Open Journal of Business and Management, 09(03), 1297-1311. https://doi.org/10.4236/ojbm.2021.93070

Office of the United States Trade Representative. (n.d.). Free Trade Agreements. https://ustr.gov/tradeagreements/free-trade-agreements/united-states-mexico-canada-agreement

Office of the United States Trade Representative. (n.d.). Ghana.https://ustr.gov/countries-regions/africa/westafrica/ghana

Ojo, O. O., Shah, S., \& Coutroubis, A. D. (2018). An overview of sustainable practices in food processing supply chain environments. IEEE International Conference on Industrial Engineering and Engineering Management, 2017-Decem, 1792-1796. https://doi.org/10.1109/IEEM.2017.8290200

Okhuysen, G., \& Bonardi, J. P. (2011). Editors' comments: The challenges of building theory by combining lenses. Academy of Management Review, 36(1), 6-11. https://doi.org/10.5465/AMR.2011.55662498

Omolara, C. (2019). Rostow's Growth Theory, Structural Transformation And Economic Development: The Nigerian Experience. International Journal of Arts \& Sciences, 12(1), 199-212.

*Osei-Amponsah, C. (2020). Innovation capabilities and learning mechanisms: insights from Ghanaian fresh fruit processing enterprises. Innovation and Development, 0-19. https://doi.org/10.1080/2157930X.2020.1845481

Owoo, N.S., \& Lambon-Quayefio, M. P. (2018). The Agro-Processing Industry and its Potential for Structural Transformation of the Ghanaian The Agro-Processing Industry and its Potential for Structural Transformation of the Ghanaian Economy for Structural Transformation of the Ghanaian Economy. Industries without Smokestacks: Industrialization in Africa Reconsidered, November 2021, 1-451. https://doi.org/10.1093/oso/9780198821885.001.0001

Owoo, Nkechi S., \& Lambon-Quayefio, M. P. (2018). The Agro-Processing Industry and its Potential for Structural Transformation of the Ghanaian Economy for Structural Transformation of the Ghanaian Economy. Industries without Smokestacks: Industrialization in Africa Reconsidered, September 2021, 1-451. https://doi.org/10.1093/oso/9780198821885.001.0001

*Panda, D. (2015). Growth determinants in small firms: drawing evidence from the Indian agro-industry. International Journal of Commerce and Management, 25(1), 52-66. https://doi.org/10.1108/IJCoMA-122012-0080

Pasquali, G., Krishnan, A., \& Engel, J. (2021). WIDER Working Paper 2021/112-Pulling up or binding down: a review of upgrading trajectories in apparel and agro-processing global value chains for developing countries. https://doi.org/10.35188/UNU-WIDER/2021/052-8

Pollock, A., \& Berge, E. (2018). How to do a systematic review. International Journal of Stroke, 13(2), $138-156$. https://doi.org/10.1177/1747493017743796

Popescu, G. H. (2014). FDI and economic growth in Central and Eastern Europe. Sustainability (Switzerland), 6(11), 8149-8163. https://doi.org/10.3390/su6118149

Porter, S. (2007). Validity, trustworthiness and rigour: Reasserting realism in qualitative research. Journal of Advanced Nursing, 60(1), 79-86. https://doi.org/10.1111/j.1365-2648.2007.04360.x

Press, S. (2017). Economic Growth. 1-7. 
Prus, P., \& Sikora, M. (2021). The impact of transport infrastructure on the sustainable development of the region - case study. Agriculture (Switzerland), 11(4), 1-15. https://doi.org/10.3390/agriculture11040279

*Rae, A., \& Josling, T. (2003). Processed food trade and developing countries: Protection and trade liberalization. Food Policy, 28(2), 147-166. https://doi.org/10.1016/S0306-9192(03)00016-2

Riaz, U., Hussain, B., \& Bhatti, A. A. (2020). Role of Structural Change in Economic Growth: An Empirical Evidence from a Panel of Asian Countries. In Liberal Arts and Social Sciences International Journal (LASSIJ) (Vol. 4, Issue 2, pp. 345-360). https://doi.org/10.47264/idea.lassij/4.2.27

Romanian, T., Journal, E., Ema, N. S., \& Jahan, H. (2020). Role of Agriculture and Manufacturing Sectors in the Economic Growth of Bangladesh and India: An ARDL Approach. Romanian Economic Journal, XXIII(78), $82-92$.

Rostow, W. W. (1959). The stages of economic growth. Sociological Worlds: Comparative and Historical Readings on Society, 12(1), 130-134. https://doi.org/10.4324/9781315063362-20

*Ruslan, S. M. M. (2018). Productivity for agro-based industrial sub-sector in Malaysia using Malmquist index. Academy of Strategic Management Journal, 17(5), 1-8.

*Sanida, O., Asafu-Adjaye, J., \& Mahadevan, R. (2016). Challenges for agricultural development in a resourcerich developing country: a case study of Papua New Guinea. Journal of the Asia Pacific Economy, 21(2), 235-256. https://doi.org/10.1080/13547860.2016.1145789

Santacoloma, P., Röttger, A., \& Tartanac, F. (2009). Business management for small-scale agro-industries. FOOD AND AGRICULTURE ORGANIZATION OF THE UNITED NATIONS.

Schmidt, V. H. (2011). How unique is east asian modernity?1. Asian Journal of Social Science, 39(3), 304-331. https://doi.org/10.1163/156853111X577596

*Shehrawat, P. S. (2006). Agro-Processing Industries---a Challenging Entrepreneurship for Rural Development. Journal of Asia Entrepreneurship and Sustainability REFEREED MATERIAL Volume II Journal of Asia Entrepreneurship and Sustainability, II(3). www.asiaentrepreneurshipjournal.com

*Shifa, A. B. (2015). Does Agricultural Growth Cause Manufacturing Growth? Economica, 82, 1107-1125. https://doi.org/10.1111/ecca.12142

Studies, S., \& Program, S. (n.d.). Application of W. W. Rostow 's “ The Stages of Economic Growth Theory ” to the Contemporary Socio-economic Development of the UAE.

Tandoh-Offin, P. (2011). A Review of Environmental Entrepreneurship as an Agenda for Rural Development: The Case for Ghana. SSRN Electronic Journal. https://doi.org/10.2139/ssrn.1520669

*Thindisa, L. M. V., \& Urban, B. (2018). Human-social capital and market access factors influencing agroprocessing participation by small-scale agripreneurs: The moderating effects of transaction costs. Acta Commercii, 18(1), 1-11. https://doi.org/10.4102/ac.v18i1.500

Thomas, J., \& Harden, A. (2008). Methods for the thematic synthesis of qualitative research in systematic reviews. BMC Medical Research Methodology, 8, 1-10. https://doi.org/10.1186/1471-2288-8-45

Titler, M. (2008). Section II: Evidence-Based Practice. Patient Safety and Quality: An Evidence-Based Handbook for Nurses, 113-132.

Tranfield, D., Denyer, D., \& Smart, P. (2003). Towards a Methodology for Developing Evidence-Informed Management Knowledge by Means of Systematic Review. British Journal of Management, 14(3), $207-222$. https://doi.org/10.1111/1467-8551.00375

*Trusova, N., Prystemskyi, O., \& Sakun, A. (2019). Financial Mechanism and Tools of Provision the Sustainable Development of Agricultural Enterprises. Accounting and Finance, 4(4(86)), 96-105. https://doi.org/10.33146/2307-9878-2019-4(86)-96-105

UNIDO. (2001). Joining forces for industrial skills development. https://www.unido.org/joining-forces-industrialskills-development

U.S. Department Of Agriculture. (n.d.). Farm Loan Programs. Https://Www.Fsa.Usda.Gov/Programs-AndServices/Farm-Loan-Programs/Index

Van Neuss, L. (2019). the Drivers of Structural Change. Journal of Economic Surveys, 33(1), $309-349$. https://doi.org/10.1111/joes. 12266

*Venkatesh, P., Balasubramanian, M., Praveen, K. V., Aditya, K. S., Babu, D. V., Nithyashree, M. L., \& Kar, A. (2017). Agro-Processing Industry and Farmers' Linkages: Pattern and Impact on Enhancing Farmers' Income in Tamil Nadu. Agricultural Economics Research Review, 30(conf), 13. https://doi.org/10.5958/09740279.2017.00018.0

*Watanabe, M., Jinji, N., \& Kurihara, M. (2009). Is the development of the agro-processing industry pro-poor?: The case of Thailand. Journal of Asian Economics, 20(4), 443-455. https://doi.org/10.1016/j.asieco.2009.04.004

*Wattanapruttipaisan, T. (2003). ASEAN-CHINA Free Trade Area: Advantages, Challenges, and Implications for the newer ASEAN Member countries.

Yao, L., Bao, C., \& Yu, J. (2013). Research on Economic Development Stage and Marginal Effects of Trade and 
FDI on Economic Growth in China. International Journal of Economics and Finance, 5(11), 37-45. https://doi.org/10.5539/ijef.v5n11p37

Yow, L. A. (2002). Success in Adding Value: The Case of the Agro-Processing Sector in Ghana, West Africa. Carolina Papers - International Studies, July 2001.

Zayone, T. I., Henneberry, S. R., \& Radmehr, R. (2020). Effects of agricultural, manufacturing, and mineral exports on Angola's economic growth. Energies, 13(6). https://doi.org/10.3390/en13061494

Zhang, W., \& Liu, G. (2017). Situation and development of worldwide agri-environment: Agricultural land uses fertilizers consumption and carbon dioxide equivalent emissions. Environmental Skeptics and Critics, 6(1), 1-8. www.iaees.org

*Zulkhibri, M., Naiya, I., \& Ghazal, R. (2015). Structural change and economic growth in selected emerging economies. International Journal of Development Issues, 14(2), 98-116. https://doi.org/10.1108/IJDI-092014-0064

Appendix A

Data Extraction Table

\begin{tabular}{|c|c|c|c|c|c|c|}
\hline $\begin{array}{l}\text { Author(s) \& year of } \\
\text { publication }\end{array}$ & Study Title & $\begin{array}{l}\text { Types of factors } \\
\text { impacting the } \\
\text { agro-processing } \\
\text { industry and/or } \\
\text { link to economic } \\
\text { growth and } \\
\text { development }\end{array}$ & Aim/Objective & $\begin{array}{l}\text { Study Design/ } \\
\text { Approach }\end{array}$ & Main findings & Implication to practice \\
\hline (Ahmed et al., 2014) & $\begin{array}{l}\text { A Nonparametric } \\
\text { Estimation of } \\
\text { Total Factor } \\
\text { Productivity } \\
\text { Growth of } \\
\text { Manufacturing } \\
\text { Firms }\end{array}$ & $\begin{array}{l}\text { Technology, } \\
\text { training, social } \\
\text { environment or } \\
\text { technical change } \\
\text { (technical } \\
\text { efficiency), } \\
\text { natural disasters, } \\
\text { open market and } \\
\text { international } \\
\text { trade, power } \\
\text { supply to agro- } \\
\text { based } \\
\text { manufacturing } \\
\text { plants, }\end{array}$ & $\begin{array}{l}\text { Used Malmquist Total } \\
\text { factor productivity } \\
\text { (TFP) to evaluate } \\
\text { factors that impact the } \\
\text { performance of agro- } \\
\text { based manufacturing } \\
\text { firms in developing } \\
\text { countries }\end{array}$ & $\begin{array}{l}\text { Follows a non- } \\
\text { parametric to } \\
\text { approach to } \\
\text { measure TFP } \\
\text { growth of } \\
\text { manufacturing } \\
\text { firms. Used } \\
\text { randomly } \\
\text { selected firm- } \\
\text { level data from } \\
2007 \text { to } 2009 \\
299 \text { firms. } 141 \\
\text { out of the } 299 \\
\text { forms fit the } \\
\text { requirements }\end{array}$ & $\begin{array}{l}\text { Key findings are that } \\
\text { Technological advancement, } \\
\text { continuity or interruption } \\
\text { energy and power inputs, lack } \\
\text { of robust social environment } \\
\text { and security, natural disasters, } \\
\text { and open, uneven and } \\
\text { opportunities for }\end{array}$ & $\begin{array}{l}\text { Managers and practitioners } \\
\text { at various manufacturing } \\
\text { firms in developing to } \\
\text { ensure to: } \\
\text { (1) Push the frontiers of } \\
\text { agro-based manufacturing } \\
\text { through technological } \\
\text { advancement } \\
\text { (2) endeavor open, free, and } \\
\text { international } \\
\text { opportunities } \\
\text { (3) continuously training } \\
\text { their employees } \\
\text { (4) beware of natural } \\
\text { disasters and how they } \\
\text { impact productivity } \\
\text { (6) power interruption is a } \\
\text { factor and so there is a need } \\
\text { to ensure there is the } \\
\text { reliable power supply }\end{array}$ \\
\hline (Munyi, 2020) & $\begin{array}{l}\text { Africa's stalled } \\
\text { structural } \\
\text { transformation: the } \\
\text { end } \\
\text { of the flying geese? }\end{array}$ & $\begin{array}{l}\text { FDI } \\
\text { Structural } \\
\text { transformation }\end{array}$ & $\begin{array}{l}\text { To understand if } \\
\text { structural } \\
\text { transformation is } \\
\text { happening in Africa, } \\
\text { and can African states } \\
\text { count on the neoliberal } \\
\text { flying geese paradigm } \\
\text { for industrialization. }\end{array}$ & $\begin{array}{l}\text { Literature } \\
\text { review with } \\
\text { quantitative } \\
\text { analysis }\end{array}$ & $\begin{array}{l}\text { Analysis of data from the } \\
\text { world bank suggests that the } \\
\text { required structural } \\
\text { transformation is not occurring } \\
\text { in Africa as it should. The } \\
\text { Huge capitalization in the G20 } \\
\text { States (especially China) has } \\
\text { stalled development in Africa } \\
\text { and other developing } \\
\text { countries, forcing most } \\
\text { African states to rely on debt } \\
\text { from China for capital } \\
\text { formation. }\end{array}$ & $\begin{array}{l}\text { FDI-based structural } \\
\text { transformation should be } \\
\text { done with care, with a } \\
\text { careful understanding of the } \\
\text { repercussions and } \\
\text { conditions. }\end{array}$ \\
\hline (Atayi et al., 2021) & $\begin{array}{l}\text { Agriculture, } \\
\text { Manufacturing and } \\
\text { Economic Growth } \\
\text { in Nigeria }\end{array}$ & $\begin{array}{l}\text { Agricultural } \\
\text { production and } \\
\text { its impact on } \\
\text { manufacturing }\end{array}$ & $\begin{array}{l}\text { This study addressed } \\
\text { "the positive effect of } \\
\text { Agriculture on the } \\
\text { manufacturing sector in } \\
\text { Nigeria." (p.337) }\end{array}$ & $\begin{array}{l}\text { Utilized } \\
\text { secondary data } \\
\text { and the } \\
\text { Ordinary Least } \\
\text { Square Method } \\
\text { estimation } \\
\text { techniques }\end{array}$ & $\begin{array}{l}\text { The study found that: } \\
\text { "The agricultural production } \\
\text { coefficient also verified the a } \\
\text { priori expectation. It has a } \\
\text { positive symbol, suggesting } \\
\text { that MVA and agricultural } \\
\text { production have a positive } \\
\text { relationship." (p.337) } \\
\text { The AGRQ coefficient is } \\
\text { ( } 0.045142 \text { ), meaning that a } 5 \% \\
\text { shift in AGRQ would result in } \\
\text { a } 5 \% \text { change in Manufacturing } \\
\text { Value Added." (p.345) }\end{array}$ & $\begin{array}{l}\text { Government can develop a } \\
\text { spend plan policy to boost } \\
\text { agricultural production and } \\
\text { manufacturing value add } \\
\text { (MVA). MVA has a direct } \\
\text { impact on GDP. }\end{array}$ \\
\hline (Adaku et al., 2018) & $\begin{array}{l}\text { Delays in new } \\
\text { product } \\
\text { introduction: } \\
\text { Experiences of a } \\
\text { food processing } \\
\text { company in a } \\
\text { developing } \\
\text { economy }\end{array}$ & $\begin{array}{l}\text {-Structure and } \\
\text { process } \\
\text {-inefficient } \\
\text { management } \\
\text {-unfavorable } \\
\text { Government } \\
\text { regulations and } \\
\text { policies }\end{array}$ & $\begin{array}{l}\text { Understanding delay } \\
\text { factors in introducing } \\
\text { new agro-based } \\
\text { products to the market }\end{array}$ & $\begin{array}{l}\text { Used the case } \\
\text { study of a large } \\
\text { processing firm } \\
\text { in Ghana and a } \\
\text { two-stage } \\
\text { survey } \\
\text { approach to } \\
\text { understand the } \\
\text { underlying } \\
\text { reasons } \\
\text { impacting } \\
\text { delayed } \\
\text { product } \\
\text { introduction to } \\
\text { the market }\end{array}$ & $\begin{array}{l}\text { Critical causes of product } \\
\text { introduction are: poor project } \\
\text { management } \\
\text { Prioritization, and } \\
\text { expertise, non-favorable } \\
\text { external factors like } \\
\text { government regulations on, for } \\
\text { example, product testing and } \\
\text { lack of communication, } \\
\text { limited production capacity }\end{array}$ & $\begin{array}{l}\text { Practitioners and } \\
\text { management to ensure the } \\
\text { labor force is trained with } \\
\text { the requisite technical skill } \\
\text { and know-how } \\
\text { Project management skills } \\
\text { and structure to be utilized. } \\
\text { Government in developing } \\
\text { countries to ensure that } \\
\text { policies and regulations in } \\
\text { place for product testing are } \\
\text { streamlined and can be } \\
\text { exercised easily by agro- } \\
\text { processing companies when } \\
\text { introducing new products to } \\
\text { the market. }\end{array}$ \\
\hline
\end{tabular}




\begin{tabular}{|c|c|c|c|c|c|c|}
\hline $\begin{array}{l}\text { Author(s) \& year of } \\
\text { publication }\end{array}$ & Study Title & $\begin{array}{l}\text { Types of factors } \\
\text { impacting the } \\
\text { agro-processing } \\
\text { industry and/or } \\
\text { link to economic } \\
\text { growth and } \\
\text { development }\end{array}$ & Aim/Objective & $\begin{array}{l}\text { Study Design/ } \\
\text { Approach }\end{array}$ & Main findings & Implication to practice \\
\hline $\begin{array}{c}\text { (Dorosh \& Thurlow, } \\
\text { 2018) }\end{array}$ & $\begin{array}{l}\text { Beyond Agriculture } \\
\text { Versus Non- } \\
\text { Agriculture: } \\
\text { Decomposing } \\
\text { Sectoral: Growth- } \\
\text { Poverty Linkages in } \\
\text { Five African } \\
\text { Countries }\end{array}$ & $\begin{array}{l}\text { Agro-processing } \\
\text { or manufacturing } \\
\text { reduces poverty } \\
\text { and boosts GDP } \\
\text { per capita }\end{array}$ & $\begin{array}{l}\text { Understanding what } \\
\text { constitutes agriculture } \\
\text { and non-agriculture and } \\
\text { how either or reduces } \\
\text { poverty }\end{array}$ & $\begin{array}{l}\text { Case study of } \\
\text { five countries: } \\
\text { Malawi } \\
\text { (MAL), } \\
\text { Mozambique } \\
\text { (MOZ), } \\
\text { Tanzania } \\
\text { (TZA), Uganda } \\
\text { (UGA), and } \\
\text { Zambia (ZAM) } \\
\text { and using } \\
\text { poverty growth } \\
\text { elasticity } \\
\text { measures }\end{array}$ & $\begin{array}{l}\text { Agro-led processing or } \\
\text { manufacturing impacts GDP } \\
\text { per capita (economic growth) } \\
\text { by reducing poverty per head } \\
\text { in households in developing }\end{array}$ & $\begin{array}{l}\text { Leaders in developing } \\
\text { countries to encourage } \\
\text { agro-based processing or } \\
\text { manufacturing } \\
\text { reducing poverty }\end{array}$ \\
\hline (Klasen et al., 2021) & $\begin{array}{lr}\text { Does } & \text { the } \\
\text { designation of least } \\
\text { developed country } \\
\text { status } & \text { promote } \\
\text { exports? } & \end{array}$ & $\begin{array}{l}\text { Least developed } \\
\text { country status } \\
\text { Export demand }\end{array}$ & $\begin{array}{l}\text { The study sought to } \\
\text { 1. "examine to what } \\
\text { extent developing } \\
\text { countries export more } \\
\text { as a result of having the } \\
\text { official reast } \\
\text { Developed Country } \\
\text { (LDC) status" } \\
2 \text {. "estimate a gravity } \\
\text { model of trade over the } \\
\text { period 1973-2013, in } \\
\text { which identification is } \\
\text { achieved by exploiting } \\
\text { the particularities and } \\
\text { asymmetries of } \\
\text { 'inclusion', and } \\
\text { 'graduation' criteria of } \\
\text { LDC status" (p.157) }\end{array}$ & $\begin{array}{l}\text { Various } \\
\text { empirical } \\
\text { analysis and } \\
\text { modeling } \\
\text { efforts, (the } \\
\text { augmented } \\
\text { gravity model } \\
\text { of trade) }\end{array}$ & $\begin{array}{l}\text { The study found that countries } \\
\text { designated as Least Developed } \\
\text { Countries (LDC) led to } \\
\text { aggregated and increased } \\
\text { exports and access to other } \\
\text { international markets. } \\
\text { Individual trade preferences } \\
\text { are not always beneficial }\end{array}$ & $\begin{array}{l}\text { Policy strategies that helped } \\
\text { to establish an environment } \\
\text { for increased exports and } \\
\text { access to local and } \\
\text { international markets. }\end{array}$ \\
\hline (Hawkes, 2005) & $\begin{array}{l}\text { The role of foreign } \\
\text { direct investment in } \\
\text { the nutrition } \\
\text { transition }\end{array}$ & $\begin{array}{l}\text { Foreign direct } \\
\text { investment }\end{array}$ & $\begin{array}{l}\text { To determine the } \\
\text { impact of foreign direct } \\
\text { investment (FDI) on } \\
\text { processed food }\end{array}$ & $\begin{array}{l}\text { Data analysis } \\
\text { and Literature } \\
\text { review }\end{array}$ & $\begin{array}{l}\text { FDI has proven more effective } \\
\text { than trade and leads to } \\
\text { increased and proliferation of } \\
\text { processed foods. } \\
\text { It creates more opportunities } \\
\text { and infrastructure for } \\
\text { accelerated production, } \\
\text { marketing, and sales of agro- } \\
\text { based manufactured foods. }\end{array}$ & $\begin{array}{l}\text { FDI as a strategy provides } \\
\text { the resources to accelerate } \\
\text { infrastructure development, } \\
\text { leading to more agro- } \\
\text { manufactured foods on the } \\
\text { market }\end{array}$ \\
\hline $\begin{array}{l}\text { (Wattanapruttipaisan, } \\
\text { 2003) }\end{array}$ & $\begin{array}{l}\text { ASEAN-CHINA } \\
\text { Free Trade Area: } \\
\text { Advantages, } \\
\text { Challenges, and } \\
\text { Implications for the } \\
\text { newer ASEAN } \\
\text { Member countries }\end{array}$ & $\begin{array}{l}\text { Foreign direct } \\
\text { investment, } \\
\text { domestic, } \\
\text { regional, and } \\
\text { international } \\
\text { trade. Free and } \\
\text { open markets for } \\
\text { agro-based or } \\
\text { manufacturing } \\
\text { products }\end{array}$ & $\begin{array}{l}\text { Uses literature and } \\
\text { secondary data to } \\
\text { establish advantages, } \\
\text { challenges, and } \\
\text { implications for the } \\
\text { newer ASEAN member } \\
\text { countries }\end{array}$ & $\begin{array}{l}\text { Not explicitly } \\
\text { stated but } \\
\text { alludes to a } \\
\text { kind of } \\
\text { literature } \\
\text { review and use } \\
\text { of secondary } \\
\text { data }\end{array}$ & $\begin{array}{l}\text { 1. China's access to ASEAN } \\
\text { free trade enables trade in } \\
\text { agro-based products with other } \\
\text { neighboring countries } \\
\text { 2. Free trade area enables } \\
\text { technological and labor } \\
\text { competitiveness } \\
\text { 3. inter-firm networking and } \\
\text { advocacy for domestic } \\
\text { entrepreneurship is focal to } \\
\text { economic growth and } \\
\text { development } \\
\text { 4. developing countries to } \\
\text { engage and allow for smart } \\
\text { foreign direct investments }\end{array}$ & $\begin{array}{l}\text { Developing nations should } \\
\text { forge and establish a free } \\
\text { trade area to allow trade of } \\
\text { agro-based manufactured } \\
\text { products among their } \\
\text { neighboring countries }\end{array}$ \\
\hline (Shehrawat, 2006) & $\begin{array}{l}\text { Agro-Processing } \\
\text { Industries---A } \\
\text { Challenging } \\
\text { Entrepreneurship } \\
\text { for Rural } \\
\text { Development }\end{array}$ & $\begin{array}{l}\text { Technology, } \\
\text { markets, efficient } \\
\text { management, } \\
\text { entrepreneurship, } \\
\text { the proximity of } \\
\text { raw materials, } \\
\text { government } \\
\text { policies, and } \\
\begin{array}{l}\text { availability of } \\
\text { capital. }\end{array}\end{array}$ & $\begin{array}{l}\text { Aimed to establish the } \\
\text { training requirement of } \\
\text { entrepreneurs to set up } \\
\text { sustainable agro-based } \\
\text { units }\end{array}$ & $\begin{array}{l}\text { A total of } 120 \\
\text { entrepreneurs } \\
\text { were used. } \\
\text { Responses } \\
\text { from each } \\
\text { entrepreneur } \\
\text { were measured } \\
\text { against } 55 \\
\text { factors on a 4- } \\
\text { point } \\
\text { continuum } \\
\text { rating scale }\end{array}$ & $\begin{array}{l}\text { The factors impacting agro- } \\
\text { based entrepreneurship are } 1 . \\
\text { Capital accessibility, 2. Access } \\
\text { markets (local and } \\
\text { international) } \\
\text { Manufacturing product quality } \\
\text { and packaging }\end{array}$ & $\begin{array}{l}\text { There is a need for nations } \\
\text { to create the enabling } \\
\text { environment for agro-based } \\
\text { entrepreneurship to access } \\
\text { capital for agro-based } \\
\text { manufacturing. Access to } \\
\text { markets is also an essential } \\
\text { requirement. However, } \\
\text { agro-based entrepreneurs } \\
\text { should look for innovative } \\
\text { ways of attractive, } \\
\text { competitive packaging of } \\
\text { agro-based manufactured } \\
\text { products }\end{array}$ \\
\hline (Sanida et al., 2016) & $\begin{array}{l}\text { Challenges for } \\
\text { agricultural } \\
\text { development in a } \\
\text { resource-rich } \\
\text { developing country: } \\
\text { a case study of } \\
\text { Papua New Guinea }\end{array}$ & $\begin{array}{l}\text { 1. Supply chain } \\
\text { constraints } \\
\text { impacts } \\
\text { manufacturing } \\
\text { output towards } \\
\text { economic } \\
\text { growth: poor } \\
\text { road } \\
\text { infrastructural } \\
\text { network } \\
2 \text {. agro-based } \\
\text { manufacturing } \\
\text { reduces poverty } \\
\text { 3. technology } \\
\text { advancement }\end{array}$ & $\begin{array}{l}\text { The study used a } \\
\text { dynamic computable } \\
\text { general equilibrium } \\
\text { model to analyze some } \\
\text { options to boost growth } \\
\text { in the agro-based } \\
\text { manufacturing sector in } \\
\text { resource-rich and } \\
\text { dependent developing } \\
\text { countries }\end{array}$ & $\begin{array}{l}\text { Case study } \\
\text { approach and } \\
\text { various } \\
\text { dynamic } \\
\text { modeling } \\
\text { approaches } \\
\text { (including } \\
\text { capital } \\
\text { utilization, } \\
\text { labor, etc.) of } \\
\text { Papua New } \\
\text { Guinea - a } \\
\text { resource-rich } \\
\text { developing } \\
\text { country }\end{array}$ & $\begin{array}{l}\text { Policy approaches in } 1 . \\
\text { Increased investment in } \\
\text { agriculture and infrastructure } \\
\text { like road networks, } 2 . \\
\text { Improved agro-based } \\
\text { manufacturing, increases } \\
\text { employment and leads to } \\
\text { economic growth through } \\
\text { employment and } \\
\text { However, poor infrastructure } \\
\text { like roads impacts } \\
\text { manufacturing outputs } \\
\text { Agro-based manufacturing } \\
\text { creates employment and } \\
\text { reduces poverty; boosting } \\
\text { economic growth }\end{array}$ & $\begin{array}{l}\text { Government to invest in } \\
\text { road infrastructure to } \\
\text { reliably transport } \\
\text { agricultural raw materials } \\
\text { from source to } \\
\text { manufacturing industries } \\
\text { Investment in agro- } \\
\text { processing to create } \\
\text { employment and reduce } \\
\text { poverty towards economic } \\
\text { growth and development } \\
\text { There should be a deliberate } \\
\text { investment in technology to } \\
\text { improve productivity in the } \\
\text { agro-based manufacturing } \\
\text { sector }\end{array}$ \\
\hline
\end{tabular}




\begin{tabular}{|c|c|c|c|c|c|c|}
\hline $\begin{array}{l}\text { Author(s) \& year of } \\
\text { publication }\end{array}$ & Study Title & $\begin{array}{l}\text { Types of factors } \\
\text { impacting the } \\
\text { agro-processing } \\
\text { industry and/or } \\
\text { link to economic } \\
\text { growth and } \\
\text { development }\end{array}$ & Aim/Objective & $\begin{array}{l}\text { Study Design/ } \\
\text { Approach }\end{array}$ & Main findings & Implication to practice \\
\hline $\begin{array}{l}\text { (Abid Sultan \& } \\
\text { Deepak, 2017) }\end{array}$ & $\begin{array}{l}\text { Competitiveness of } \\
\text { agro-processing } \\
\text { firms: productivity } \\
\text { approach }\end{array}$ & $\begin{array}{l}\text { Technology } \\
\text { and/or technical } \\
\text { efficiencies }\end{array}$ & $\begin{array}{lr}\text { The study measures } \\
\text { total } & \text { factor } \\
\text { measurement } & \text { on agro- } \\
\text { processing } & \end{array}$ & $\begin{array}{l}\text { Uses the } \\
\text { Malmquist } \\
\text { productivity } \\
\text { index (MPI_to } \\
\text { measure the } \\
\text { productivity of } \\
\text { the agro- } \\
\text { processing } \\
\text { industry }\end{array}$ & $\begin{array}{l}\text {-slow growth in the agro- } \\
\text { processing industry decreases } \\
\text { employment } \\
\text { - productivity regress of the } \\
\text { agro-processing industry is } \\
\text { due to technical inefficiencies }\end{array}$ & $\begin{array}{l}\text { Practitioners to ensure the } \\
\text { resources are trained with } \\
\text { the right technical skillset to } \\
\text { increase productivity } \\
\text {-lack of growth leads to } \\
\text { unemployment and poverty }\end{array}$ \\
\hline (Shifa, 2015) & $\begin{array}{l}\text { Does Agricultural } \\
\text { Growth Cause } \\
\text { Manufacturing } \\
\text { Growth? }\end{array}$ & $\begin{array}{l}\text { Competitive } \\
\text { business } \\
\text { environment } \\
\text {-marketing } \\
\text {-trade }\end{array}$ & $\begin{array}{lr}\text { The study was } \\
\text { interested }\end{array}$ & $\begin{array}{l}\text { Used } \\
\text { regression } \\
\text { analysis }\end{array}$ & $\begin{array}{l}\text { A competitive market and } \\
\text { business environment is } \\
\text { necessary to promote } \\
\text { agricultural growth towards } \\
\text { agro-based manufacturing } \\
\text {-economies that open to trade }\end{array}$ & $\begin{array}{l}\text { Nations to enable a } \\
\text { competitive business } \\
\text { environment that allows the } \\
\text { growth of the agricultural } \\
\text { growth towards } \\
\text { manufacturing growth. } \\
\text { Nations to ensure their } \\
\text { economies are open to trade }\end{array}$ \\
\hline (Martin, 2019) & $\begin{array}{l}\text { Economic growth, } \\
\text { convergence, and } \\
\text { agricultural } \\
\text { economics }\end{array}$ & $\begin{array}{l}\text {-Taxation and } \\
\text { trade expansion } \\
\text {-Road } \\
\text { infrastructure }\end{array}$ & $\begin{array}{l}\text { aims to identify the key } \\
\text { ways in which the } \\
\text { changes in rich and } \\
\text { poor country growth } \\
\text { rates matter for } \\
\text { agricultural } \\
\text { economists, as a basis } \\
\text { for formulating better } \\
\text { research agendas. }\end{array}$ & $\begin{array}{l}\text { Literature } \\
\text { review and } \\
\text { lecture }\end{array}$ & $\begin{array}{l}\text { Used literature review and a } \\
\text { lecture style to recommend } 1 . \\
\text { the need for lower taxes, which } \\
\text { allows for expansion in trade } \\
\text { and markets for products } \\
2 \text {. Poor investments in } \\
\text { infrastructural road systems is } \\
\text { a great constraint }\end{array}$ & $\begin{array}{l}\text { Government to enable } \\
\text { policies that reduce taxes on } \\
\text { agricultural products - } \\
\text { expanding trade locally and } \\
\text { internationally. Developing } \\
\text { countries to invest }\end{array}$ \\
\hline (Trusova et al., 2019) & $\begin{array}{l}\text { Financial } \\
\text { Mechanism and } \\
\text { Tools of Provision } \\
\text { the Sustainable } \\
\text { Development of } \\
\text { Agricultural } \\
\text { Enterprises }\end{array}$ & $\begin{array}{l}\text { Budget } \\
\text { constraints } \\
\text { without state } \\
\text { support and } \\
\text { options - process } \\
\text { and structure }\end{array}$ & $\begin{array}{l}\begin{array}{l}\text { Expand on the } \\
\text { theoretical } \\
\text { methodological and } \\
\text { foundations of a } \\
\text { financial system } \\
\text { supporting agricultural } \\
\text { enterprises }\end{array} \\
\end{array}$ & $\begin{array}{l}\text { The theoretical } \\
\text { and } \\
\text { methodological } \\
\text { approach }\end{array}$ & $\begin{array}{l}\text { A financial policy or } \\
\text { regulation for sustainable } \\
\text { development is contingent on } \\
\text { the structural systems in place } \\
\text { for finance }\end{array}$ & Good financial policies \\
\hline (Dao, 2016) & $\begin{array}{l}\text { From agriculture to } \\
\text { manufacturing: } \\
\text { How does } \\
\text { geography matter? }\end{array}$ & $\begin{array}{l}\text {-Geography } \\
\text {-Technology }\end{array}$ & $\begin{array}{l}\text { To advance a theory } \\
\text { about the impact of } \\
\text { geography on } \\
\text { agricultural production, } \\
\text { manufacturing } \\
\text { (industrialization), } \\
\text { technology, and labor }\end{array}$ & Theoretical & $\begin{array}{l}\text { The theory proves that the } \\
\text { geography of agricultural } \\
\text { production could delay } \\
\text { manufacturing and } \\
\text { industrialization. Geography is } \\
\text { proven to have a direct impact } \\
\text { on obtaining skilled labor } \\
\text { required to support } \\
\text { technological advancement }\end{array}$ & $\begin{array}{l}\text { Leaders in development } \\
\text { need to understand that the } \\
\text { geography of agricultural } \\
\text { production can impact agro- } \\
\text { manufacturing and } \\
\text { industrialization. It has an } \\
\text { impact on labor structure } \\
\text { and technological } \\
\text { advancement }\end{array}$ \\
\hline (Panda, 2015) & $\begin{array}{l}\text { Growth } \\
\text { determinants in } \\
\text { small firms: } \\
\text { drawing evidence } \\
\text { from the Indian } \\
\text { agro-industry }\end{array}$ & $\begin{array}{l}\text { Management } \\
\text { intensity, skilled } \\
\text { labor, } \\
\text { technology, open } \\
\text { and accessible } \\
\text { markets }\end{array}$ & $\begin{array}{l}\text { To find the } \\
\text { determinants of growth } \\
\text { of small agro-based } \\
\text { enterprises in India }\end{array}$ & $\begin{array}{l}\text { Data was } \\
\text { collected using } \\
\text { a stratified } \\
\text { random } \\
\text { sampling } \\
\text { method. A } \\
\text { structured but } \\
\text { pretested } \\
\text { questionnaire } \\
\text { was used to } \\
\text { collect data. } \\
\text { Data analysis } \\
\text { by a descriptive } \\
\text { statistics and } \\
\text { multivariate } \\
\text { technique }\end{array}$ & 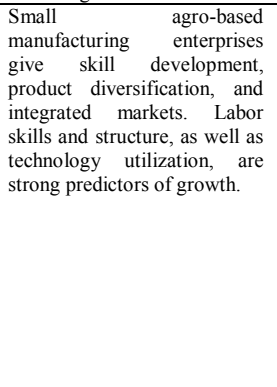 & $\begin{array}{l}\text { Practitioners to endeavor } \\
\text { continuously train and } \\
\text { development talents while } \\
\text { exposing them to the } \\
\text { needed technologies. } \\
\text { Advancement in product } \\
\text { diversification and access } \\
\text { markets, both locally and } \\
\text { internationally) should be } \\
\text { prioritized. These factor } \\
\text { areas align small firms to } \\
\text { rapidly scale and contribute } \\
\text { to manufacturing growth } \\
\text { and industrialization in } \\
\text { developing countries }\end{array}$ \\
\hline (Ruslan, 2018) & $\begin{array}{l}\text { Productivity } \\
\text { Agro-Based } \\
\text { Industrial Sub- } \\
\text { Sector in Malaysia } \\
\text { Using Malmquist } \\
\text { Index }\end{array}$ & $\begin{array}{l}\text { Technical } \\
\text { efficiency and } \\
\text { availability of } \\
\text { technology }\end{array}$ & $\begin{array}{l}\text { Used the Malmquist } \\
\text { productivity index to } \\
\text { observe the } \\
\text { productivity efficiency } \\
\text { trend of the agro-based } \\
\text { industry in Malaysia }\end{array}$ & $\begin{array}{l}\text { Malmquist } \\
\text { productivity } \\
\text { index (MPI) to } \\
\text { measure } \\
\text { productivity }\end{array}$ & $\begin{array}{l}\text { Malmquist productivity index } \\
\text { (MPI) showed that technical } \\
\text { factor/efficiency, rebranding, } \\
\text { expanded marketing strategy } \\
\text { for cocoa processing subsector } \\
\text { of the agro-based industry in } \\
\text { Malaysia led to increased } \\
\text { productivity and access to } \\
\text { markets }\end{array}$ & $\begin{array}{l}\text { A strategy to enhance } \\
\text { technical efficiency for a } \\
\text { certain product of choice } \\
\text { (cocoa, coffee, etc.) is } \\
\text { essential for productivity. } \\
\text { Also, a strategy to brand } \\
\text { and rebrand agro- } \\
\text { manufactured products is } \\
\text { key to accessing bigger and } \\
\text { integrated markets, locally } \\
\text { and internationally. }\end{array}$ \\
\hline (Kodama, 2017) & $\begin{array}{l}\text { How strongly can } \\
\text { industrial structural } \\
\text { transformation } \\
\text { affect GDP? }\end{array}$ & $\begin{array}{l}\text { Structural } \\
\text { transformation } \\
\text { leads to GDP } \\
\text { growth } \\
\text { Access and } \\
\text { availability of } \\
\text { Land and low } \\
\text { agricultural total } \\
\text { factor } \\
\text { productivity }\end{array}$ & $\begin{array}{l}\text { The study was focused } \\
\text { on the measure of the } \\
\text { impact of industrial } \\
\text { structural } \\
\text { transformation } \\
\text { (agriculture to non- } \\
\text { agriculture sectors) on } \\
\text { GDP }\end{array}$ & $\begin{array}{l}\text { Using Japanese } \\
\text { agricultural } \\
\text { data to estimate } \\
\text { GDP growth } \\
\text { and Survey } \\
\text { data of the } \\
\text { Farm } \\
\text { Household } \\
\text { Economy } \\
\text { (SFHE) }\end{array}$ & $\begin{array}{l}\text { Comparison between Japan's } \\
\text { Actual GDP and } \\
\text { counterfactual GDP, which is } \\
\text { specialization in agriculture } \\
\text { only, shows that Japan's GDP } \\
\text { will decrease by a tenth if } \\
\text { Japan specializes in } \\
\text { agriculture only. Japan's GDP } \\
\text { will }\end{array}$ & $\begin{array}{l}\text { Government to invest in } \\
\text { arable land, to ensure there } \\
\text { is increased agricultural } \\
\text { productivity. The strategy } \\
\text { to invest in the industrial } \\
\text { structural transformation } \\
\text { from solely agriculture } \\
\text { production to agro-based } \\
\text { manufacturing and } \\
\text { industrialization. }\end{array}$ \\
\hline
\end{tabular}




\begin{tabular}{|c|c|c|c|c|c|c|}
\hline $\begin{array}{l}\text { Author(s) \& year of } \\
\text { publication }\end{array}$ & Study Title & $\begin{array}{l}\text { Types of factors } \\
\text { impacting the } \\
\text { agro-processing } \\
\text { industry and/or } \\
\text { link to economic } \\
\text { growth and } \\
\text { development }\end{array}$ & Aim/Objective & $\begin{array}{l}\text { Study Design/ } \\
\text { Approach }\end{array}$ & Main findings & Implication to practice \\
\hline (Manonmani, 2015) & $\begin{array}{l}\text { Impact of Global } \\
\text { Economic Crisis on } \\
\text { the Productivity } \\
\text { Performance of } \\
\text { Agro-based } \\
\text { Industries in India: } \\
\text { A Malmquist DEA } \\
\text { Approach }\end{array}$ & $\begin{array}{l}\begin{array}{l}\text { Technical } \\
\text { efficiency and } \\
\text { scale }\end{array} \\
\begin{array}{l}\text { Technology } \\
\text { change }\end{array} \\
\begin{array}{l}\text { Scaling factor } \\
\text { and challenges }\end{array}\end{array}$ & $\begin{array}{l}\text { The study was focused } \\
\text { on finding the total } \\
\text { factor productivity of } \\
\text { agro-based industries in } \\
\text { India, in the global } \\
\text { economic crisis period } \\
\text { of 2008-2009, }\end{array}$ & 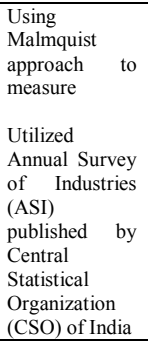 & $\begin{array}{l}\text { The analysis showed that the } \\
\text { manufacture of wood and } \\
\text { wood products has the best } \\
\text { performance due to technical } \\
\text { and scale efficiencies - } \\
\text { implication that technical } \\
\text { efficiency and technology } \\
\text { utilization is a growth factor. } \\
\text { This helps agro-based } \\
\text { manufacturing to survive in } \\
\text { the wake of the global } \\
\text { economic crisis. }\end{array}$ & $\begin{array}{l}\text { Management of agro-based } \\
\text { industries in developing } \\
\text { countries needs to focus on } \\
\text { technical efficiency and } \\
\text { technology advancement } \\
\text { and scale in the processing } \\
\text { of raw materials and } \\
\text { marketing. }\end{array}$ \\
\hline $\begin{array}{c}\text { (Watanabe et al., } \\
\text { 2009) }\end{array}$ & $\begin{array}{l}\text { Is the development } \\
\text { of the agro- } \\
\text { processing industry } \\
\text { pro-poor? The case } \\
\text { of Thailand }\end{array}$ & $\begin{array}{l}\text { Agro-based } \\
\text { industry boosts } \\
\text { economic growth } \\
\text { and reduces } \\
\text { poverty } \\
\text { Employment } \\
\text { creation }\end{array}$ & $\begin{array}{l}\text { Examine how the } \\
\text { development of the } \\
\text { agro-based industry } \\
\text { leads to poverty } \\
\text { reduction }\end{array}$ & $\begin{array}{l}\text { A quantitative } \\
\text { study utilizing } \\
\text { data from both } \\
\text { the National } \\
\text { Economic and } \\
\text { Social } \\
\text { Development } \\
\text { Board } \\
\text { (NESDB) and } \\
\text { the LFS and the } \\
\text { Household } \\
\text { Socio- } \\
\text { Economic } \\
\text { Survey (SES) } \\
\text { published by } \\
\text { the National } \\
\text { Statistical } \\
\text { Office (NSO) } \\
\text { of Thailand for } \\
\text { the analysis }\end{array}$ & $\begin{array}{l}\text { The quantitative analysis } \\
\text { showed that agro-based } \\
\text { industry creates more } \\
\text { employment and gets the poor } \\
\text { in the country employed. } \\
\text { Farmer's income increases } \\
\text { through two channels: } \\
\text { 1. purchasing of agricultural } \\
\text { products by ago-based } \\
\text { manufacturing industries leads } \\
\text { to increased agricultural } \\
\text { manufacturing } \\
\text { 2. employment of the poor in } \\
\text { agro-based processing or } \\
\text { manufacturing industries }\end{array}$ & $\begin{array}{l}\text { Agro-based } \\
\text { industrialization is critical } \\
\text { when the economy is at its } \\
\text { developing stages of } \\
\text { industrialization }\end{array}$ \\
\hline $\begin{array}{c}\text { (Mashimba \& Kühl, } \\
\text { 2014) }\end{array}$ & $\begin{array}{l}\text { Performance of } \\
\text { Micro and Small- } \\
\text { Scale Enterprises } \\
\text { (MSEs) in } \\
\text { Tanzania: Growth } \\
\text { Hazards of Fruit and } \\
\text { Vegetables } \\
\text { Processing } \\
\text { Vendors }\end{array}$ & & $\begin{array}{l}\text { To analyze the growth } \\
\text { performance of } \\
\text { smallholder agro-based } \\
\text { enterprises on the } \\
\text { processing of Tanzania }\end{array}$ & & $\begin{array}{l}\text { The study showed that factors } \\
\text { below slowed the growth of } \\
\text { small and medium scale agro- } \\
\text { based industries for several } \\
\text { reasons such as: } \\
\text { 1. Access to operational } \\
\text { capital } \\
\text { 2. access to market sources and } \\
\text { information } \\
\text { 3. Owner experience } 4 . \\
\text { Supportive systems }\end{array}$ & \\
\hline $\begin{array}{c}\text { (Rae \& Josling, } \\
2003)\end{array}$ & $\begin{array}{l}\text { Processed food } \\
\text { trade } \\
\text { developing and } \\
\text { countries: } \\
\text { protection and trade } \\
\text { liberalization }\end{array}$ & $\begin{array}{l}\text { Impact of trade- } \\
\text { economic growth }\end{array}$ & $\begin{array}{l}\text { Used the comparative } \\
\text { static approach to } \\
\text { quantify the impact of } \\
\text { trade liberation in } \\
\text { developed and } \\
\text { developing countries }\end{array}$ & $\begin{array}{l}\text { An applied } \\
\text { general } \\
\text { equilibrium } \\
\text { model }\end{array}$ & $\begin{array}{l}\text { Lowering of agricultural trade } \\
\text { barriers by the developed } \\
\text { countries resulted in increased } \\
\text { processed food exports from } \\
\text { all of the modeled developing } \\
\text { regions, their total value } \\
\text { increasing by } 6 \text { percent above } \\
\text { the base value, at the expense } \\
\text { of exports from developed } \\
\text { countries. }\end{array}$ & $\begin{array}{l}\text { Governments of developing } \\
\text { countries to should policy to } \\
\text { liber }\end{array}$ \\
\hline $\begin{array}{c}\text { (Osei-Amponsah, } \\
2020)\end{array}$ & $\begin{array}{l}\text { Innovation } \\
\text { capabilities and } \\
\text { learning } \\
\text { mechanisms: } \\
\text { insights from } \\
\text { Ghanaian fresh fruit } \\
\text { processing } \\
\text { enterprises } \\
\end{array}$ & $\begin{array}{l}\begin{array}{l}\text { Innovation } \\
\text { capability }\end{array} \\
\text { Knowledge } \\
\text { development } \\
\text { Technology } \\
\text { management }\end{array}$ & $\begin{array}{l}\text { a multi-case qualitative } \\
\text { research approach to } \\
\text { understand innovation } \\
\text { capability building } \\
\text { processes for }\end{array}$ & $\begin{array}{l}\text { Multi-case } \\
\text { qualitative } \\
\text { research } \\
\text { approach (case } \\
\text { study approach }\end{array}$ & $\begin{array}{l}\text { The key findings are in the } \\
\text { area of learning by doing and } \\
\text { context-specific intervention } \\
\text { The findings stressed the need } \\
\text { for policy to enable enhanced } \\
\text { technology and capability } \\
\text { management }\end{array}$ & $\begin{array}{l}\text { Contest-based learning and } \\
\text { policy for technology } \\
\text { advancement }\end{array}$ \\
\hline $\begin{array}{c}\text { (Breisinger et al., } \\
\text { 2009) }\end{array}$ & $\begin{array}{lr}\text { Modeling } & \text { growth } \\
\text { options } & \text { and } \\
\text { structural change to } \\
\text { reach middle- } \\
\text { income country } \\
\text { status: The case of } \\
\text { Ghana }\end{array}$ & $\begin{array}{l}\text { Agricultural } \\
\text { production of } \\
\text { raw materials } \\
\text { Increased exports } \\
\text { Labor } \\
\text { Capital } \\
\text { investment }\end{array}$ & 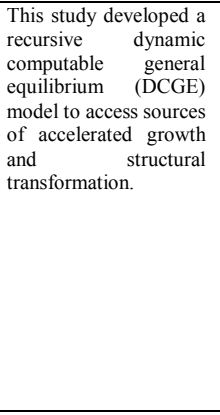 & $\begin{array}{l}\text { recursive } \\
\text { dynamic } \\
\text { computable } \\
\text { general } \\
\text { equilibrium } \\
\text { (DCGE) model }\end{array}$ & $\begin{array}{l}\text { The study showed that there is } \\
\text { increased export for } \\
\text { manufacturing goods than } \\
\text { other sectors. High primary } \\
\text { agricultural product export can } \\
\text { be replaced by high agro- } \\
\text { processing products, with } \\
\text { value-added content. } \\
\text { Manufacturing growth, } \\
\text { including agro-processing can } \\
\text { be accelerated by high capital } \\
\text { investment } \\
\begin{array}{l}\text { Agricultural production } \\
\text { (input) accelerates } \\
\text { manufacturing growth }\end{array}\end{array}$ & $\begin{array}{l}\text { Manufacturing growth is } \\
\text { enhanced with capital } \\
\text { investment coupled with } \\
\text { increased focus and } \\
\text { increased agricultural input } \\
\text { productivity. The policies, } \\
\text { institutional reforms, and } \\
\text { public investments should } \\
\text { focus on agricultural } \\
\text { productivity and economic } \\
\text { and structural } \\
\text { transformation. }\end{array}$ \\
\hline $\begin{array}{l}\text { (Bjornlund et al., } \\
2020)\end{array}$ & $\begin{array}{l}\text { Why agricultural } \\
\text { production in sub- } \\
\text { Saharan Africa } \\
\text { remains low } \\
\text { compared to the rest } \\
\text { of the world - a } \\
\text { historical } \\
\text { perspective }\end{array}$ & $\begin{array}{l}\text { External } \\
\text { factors/systems: } \\
\text { IMF }\end{array}$ & $\begin{array}{l}\text { Tracing the role of } \\
\text { agriculture through } \\
\text { history in sub-Saharan } \\
\text { Africa. }\end{array}$ & $\begin{array}{l}\text { Literature } \\
\text { review }\end{array}$ & $\begin{array}{l}\text { The key finding is that external } \\
\text { factors manipulated the } \\
\text { agricultural production and } \\
\text { manufacturing systems to } \\
\text { favor the export of raw } \\
\text { materials, inhibiting Africa's } \\
\text { growth and development. }\end{array}$ & $\begin{array}{l}\text { Leaders should be mindful } \\
\text { of how much dependence } \\
\text { they have on external } \\
\text { organizations like IMF, and } \\
\text { developed governments. } \\
\text { Rather focus on organic } \\
\text { growth using endogenous } \\
\text { growth factors }\end{array}$ \\
\hline
\end{tabular}




\begin{tabular}{|c|c|c|c|c|c|c|}
\hline $\begin{array}{l}\text { Author(s) \& year of } \\
\text { publication }\end{array}$ & Study Title & $\begin{array}{l}\text { Types of factors } \\
\text { impacting the } \\
\text { agro-processing } \\
\text { industry and/or } \\
\text { link to economic } \\
\text { growth and } \\
\text { development }\end{array}$ & Aim/Objective & $\begin{array}{l}\text { Study Design/ } \\
\text { Approach }\end{array}$ & Main findings & Implication to practice \\
\hline $\begin{array}{l}\text { (de Vries et al., } \\
2015)\end{array}$ & $\begin{array}{l}\text { Africa's stalled } \\
\text { structural } \\
\text { transformation: the } \\
\text { end of the flying } \\
\text { geese? }\end{array}$ & $\begin{array}{l}\text { Structural } \\
\text { transformation } \\
\text { for economic } \\
\text { growth } \\
\text { Trade } \\
\text { Transportation } \\
\text { Access Markets }\end{array}$ & $\begin{array}{l}\text { African growth } \\
\text { experience, long-run, } \\
\text { and international } \\
\text { perspective, } \\
\text { emphasizing the } \\
\text { movements of labor } \\
\text { across sectors and its } \\
\text { impact on aggregate } \\
\text { productivity growth. }\end{array}$ & $\begin{array}{l}\text { Parsimonious } \\
\text { approach: a } \\
\text { literature and } \\
\text { leveraging } \\
\text { secondary data }\end{array}$ & $\begin{array}{l}\text { Structural transformation is } \\
\text { growth-enhancing and } \\
\text { accounts for manufacturing } \\
\text { productivity }\end{array}$ & $\begin{array}{l}\text { Strategy to accelerate } \\
\text { manufacturing growth is } \\
\text { encouraged }\end{array}$ \\
\hline (Ncube, 2018) & 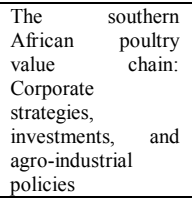 & $\begin{array}{l}\text { Trade } \\
\text { Policies } \\
\text { Favorable } \\
\text { business } \\
\text { environment }\end{array}$ & $\begin{array}{l}\text { This paper adopts a } \\
\text { modular approach to } \\
\text { understand the } \\
\text { governance structures } \\
\text { in the poultry value } \\
\text { chains in Botswana, } \\
\text { South Africa, Zambia, } \\
\text { and Zimbabwe. }\end{array}$ & $\begin{array}{l}\text { Descriptive } \\
\text { framework } \\
\text { approach. } \\
\text { Primary and } \\
\text { secondary data } \\
\text { approaches }\end{array}$ & $\begin{array}{l}\text { The study found: } \\
\text { 1. many stakeholders influence } \\
\text { the poultry value-chain, } \\
\text { depending on the formality of } \\
\text { the A policy geared at } \\
2 \text {. A the } \\
\text { streamlining the regional value } \\
\text { chain is critical }\end{array}$ & $\begin{array}{l}\text { Leaders of developing } \\
\text { counties formulate trade } \\
\text { policies that help to } \\
\text { encourage productivity and } \\
\text { streamline the value chain } \\
\text { process for agro-based } \\
\text { manufactured and and } \\
\text { processing foods. }\end{array}$ \\
\hline $\begin{array}{l}\text { (Caselli \& Coleman } \\
\text { II, 2001) }\end{array}$ & $\begin{array}{l}\text { The US structural } \\
\text { transformation and } \\
\text { regional } \\
\text { convergence: A } \\
\text { Reinterpretation }\end{array}$ & $\begin{array}{l}\begin{array}{l}\text { Structural } \\
\text { transformation }\end{array} \\
\text { Labor shift from } \\
\text { agricultural } \\
\text { production to } \\
\text { non-agricultural } \\
\text { manufacturing } \\
\text { efforts }\end{array}$ & $\begin{array}{l}\text { It is a joint study of US } \\
\text { structural } \\
\text { transformation and } \\
\text { regional convergence }\end{array}$ & $\begin{array}{l}\text { Model of } \\
\text { structural } \\
\text { transformation } \\
\text { and regional } \\
\text { convergence }\end{array}$ & $\begin{array}{l}\text { The study finds that regional } \\
\text { convergence of wages is partly } \\
\text { due to structural } \\
\text { transformation. Structural } \\
\text { transformation leads to labor } \\
\text { shifts to non-agricultural } \\
\text { value-add activities }\end{array}$ & $\begin{array}{l}\text { Leaders to develop policies } \\
\text { to cover regional } \\
\text { convergence instead of } \\
\text { creating wage disparities. } \\
\text { Structural transformation } \\
\text { leads to labor shift from } \\
\text { agricultural production to } \\
\text { non-agricultural } \\
\text { manufacturing }\end{array}$ \\
\hline $\begin{array}{l}\text { (Thindisa \& Urban, } \\
\text { 2018) }\end{array}$ & $\begin{array}{l}\text { Human-social } \\
\text { capital and market } \\
\text { access factors } \\
\text { influencing agro- } \\
\text { processing } \\
\text { participation by } \\
\text { small-scale } \\
\text { agripreneurs: The } \\
\text { moderating effects } \\
\text { of transaction costs }\end{array}$ & $\begin{array}{l}\text { Human capital: } \\
\text { skilled labor, } \\
\text { education, and } \\
\text { training } \\
\text { Social capital }\end{array}$ & $\begin{array}{l}\text { The study is about } \\
\text { human and social } \\
\text { capital factors while } \\
\text { accounting for the } \\
\text { moderating effects of } \\
\text { transaction costs. }\end{array}$ & Questionnaires & $\begin{array}{l}\text { The key findings are that } \\
\text { human (previous education } \\
\text { and training) and social capital } \\
\text { factors influence agro- } \\
\text { processing plant }\end{array}$ & $\begin{array}{l}\text { Policy on how human } \\
\text { capital factors such as } \\
\text { previous education and } \\
\text { experience impact } \\
\text { participation in agro- } \\
\text { processing activities and } \\
\text { help to mitigate transaction } \\
\text { costs are essential }\end{array}$ \\
\hline (Ahmad, 2020) & $\begin{array}{l}\text { Unlocking the } \\
\text { potentials of Micro } \\
\text { and Small } \\
\text { Enterprises (MSEs) } \\
\text { in building local } \\
\text { technological } \\
\text { capabilities in the } \\
\text { agro-processing } \\
\text { industry }\end{array}$ & 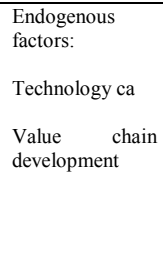 & $\begin{array}{l}\text { This research feeds into } \\
\text { establishing ways of } \\
\text { advancing Africa's } \\
\text { effort to } \\
\text { industrialization. } \\
\text { Investigated the } \\
\text { difference between } \\
\text { local production and } \\
\text { technological } \\
\text { production }\end{array}$ & $\begin{array}{l}\text { Mixed research } \\
\text { method: } \\
\text { Qualitative and } \\
\text { Qualitative } \\
\text { analysis }\end{array}$ & 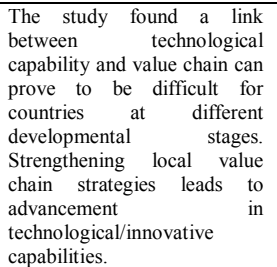 & $\begin{array}{l}\text { Practitioners to ensure } \\
\text { strategies and policies that } \\
\text { enable local value chain } \\
\text { development can lead to } \\
\text { technological } \\
\text { innovativeness. }\end{array}$ \\
\hline $\begin{array}{c}\text { (Venkatesh et al., } \\
\text { 2017) }\end{array}$ & $\begin{array}{l}\text { Agro-Processing } \\
\text { Industry and } \\
\text { Farmers' Linkages: } \\
\text { Pattern and Impact } \\
\text { on Enhancing } \\
\text { Farmers' Income in } \\
\text { Tamil Nadu }\end{array}$ & $\begin{array}{l}\begin{array}{l}\text { Poverty } \\
\text { reduction }\end{array} \\
\text { Export demand } \\
\text { Raw materials } \\
\begin{array}{l}\text { Government } \\
\text { policy }\end{array}\end{array}$ & $\begin{array}{l}\text { The purpose of the } \\
\text { study was "to assess the } \\
\text { linkage mechanisms } \\
\text { and institutional } \\
\text { arrangements between } \\
\text { farmers and markets } \\
\text { and also to quantify the } \\
\text { extent of income gains } \\
\text { across the marketing } \\
\text { channel, particularly in } \\
\text { the processor and non- } \\
\text { processor outlets" } \\
\text { (p.24) }\end{array}$ & $\begin{array}{l}\text { A } \\
\text { comprehensive } \\
\text { survey } \\
\text { approach using } \\
\text { primary and } \\
\text { secondary data. }\end{array}$ & $\begin{array}{l}\text { Based on the comprehensive } \\
\text { approach and analysis, the } \\
\text { study found growth in many } \\
\text { agro-processing companies. } \\
\text { The growth factors include } \\
\text { 1. increased export demand } \\
\text { 2. proximity and availability of } \\
\text { raw materials } \\
\text { 3. government policy } \\
\text { incentive. } \\
\text { Farmers linked to agro- } \\
\text { processing got increased } \\
\text { income. An indication of } \\
\text { continuous employment } \\
\text { towards poverty reduction. } \\
\text { "The empirical evidence } \\
\text { suggests that with the } \\
\text { emergence of processing } \\
\text { industry in major mango } \\
\text { growing areas, the farmers' } \\
\text { income would increase to the } \\
\text { extent of } 49 \text { percent" (p.24) }\end{array}$ & $\begin{array}{l}\text { Government policy } \\
\text { incentive that facilitates a } \\
\text { business environment for } \\
\text { increased exports and } \\
\text { production of agricultural } \\
\text { raw materials to support } \\
\text { agro- } \\
\text { processing/manufacturing. }\end{array}$ \\
\hline
\end{tabular}


Appendix B

Critical Appraisal Using TAPUPAS

\begin{tabular}{|c|c|c|c|c|c|c|c|c|c|c|}
\hline $\begin{array}{c}\text { Item } \\
\#\end{array}$ & Study Title & Author(s) & $\begin{array}{l}\text { Transparency } \\
\text { (T) }\end{array}$ & $\begin{array}{c}\text { Accuracy } \\
\text { (A) }\end{array}$ & $\begin{array}{l}\text { Purposivity } \\
\text { (P) }\end{array}$ & $\begin{array}{l}\text { Utility } \\
\text { (U) }\end{array}$ & $\begin{array}{l}\text { Propriety } \\
(\mathrm{P})\end{array}$ & $\begin{array}{l}\text { Accessibility } \\
\text { (A) }\end{array}$ & $\begin{array}{l}\text { Specificity } \\
\text { (S) }\end{array}$ & Score \\
\hline 1 & $\begin{array}{l}\text { A Nonparametric Estimation of } \\
\text { Total Factor Productivity } \\
\text { Growth of } \\
\text { Manufacturing Firms }\end{array}$ & (Ahmed et al., 2014) & $3(\mathrm{H})$ & $3(\mathrm{H})$ & $3(\mathrm{H})$ & $3(\mathrm{H})$ & $3(\mathrm{H})$ & $3(\mathrm{H})$ & 3(M) & 20 \\
\hline 2 & $\begin{array}{l}\text { Agriculture, Manufacturing and } \\
\text { Economic Growth in Nigeria }\end{array}$ & (Atayi et al., 2021) & $3(\mathrm{H})$ & $3(\mathrm{H})$ & $3(\mathrm{H})$ & $2(\mathrm{M})$ & 2(M) & $3(\mathrm{H})$ & $3(\mathrm{M})$ & 19 \\
\hline 3 & $\begin{array}{l}\text { Delays in new product } \\
\text { introduction } \\
\begin{array}{l}\text { Experiences of a food } \\
\text { processing company in a } \\
\text { developing economy }\end{array} \\
\end{array}$ & (Adaku et al., 2018) & $3(\mathrm{H})$ & $3(\mathrm{H})$ & $3(\mathrm{H})$ & $3(\mathrm{H})$ & 2(M) & $3(\mathrm{H})$ & $3(\mathrm{H})$ & 21 \\
\hline 4 & $\begin{array}{l}\text { Beyond Agriculture Versus } \\
\text { Non-Agriculture: } \\
\text { Decomposing Sectoral: } \\
\text { Growth-Poverty Linkages in } \\
\text { Five African Countries } \\
\end{array}$ & $\begin{array}{c}\text { (Dorosh \& Thurlow, } \\
2018)\end{array}$ & $3(\mathrm{H})$ & $3(\mathrm{H})$ & $3(\mathrm{M})$ & $3(\mathrm{H})$ & 2(M) & $3(\mathrm{H})$ & 2(M) & 19 \\
\hline 5 & $\begin{array}{l}\text { Competitiveness of agro- } \\
\text { processing firms: productivity } \\
\text { approach }\end{array}$ & $\begin{array}{l}\text { (Abid Sultan \& } \\
\text { Deepak, 2017) }\end{array}$ & 2(M) & $2(\mathrm{M})$ & $2(\mathrm{M})$ & $2(\mathrm{M})$ & 2(M) & 2(M) & $3(\mathrm{H})$ & 15 \\
\hline 6 & $\begin{array}{l}\text { Does the designation of least } \\
\text { developed country status } \\
\text { promote exports? }\end{array}$ & (Klasen et al., 2021) & $2(\mathrm{M})$ & $2(\mathrm{M})$ & $3(\mathrm{H})$ & $3(\mathrm{H})$ & $3(\mathrm{H})$ & $1(\mathrm{~L})$ & $3(\mathrm{H})$ & 17 \\
\hline 7 & $\begin{array}{l}\text { Financial Mechanism and } \\
\text { Tools of Provision the } \\
\text { Sustainable Development of } \\
\text { Agricultural Enterprises }\end{array}$ & (Trusova et al., 2019) & 2(M) & 2(M) & $2(\mathrm{M})$ & 2(M) & 2(M) & 2(M) & 2(M) & 14 \\
\hline 8 & $\begin{array}{l}\text { From agriculture } \\
\text { manufacturing: How } \\
\text { geography matter? }\end{array}$ & (Dao, 2016) & 2(M) & 2(M) & $3(\mathrm{H})$ & $2(\mathrm{M})$ & 2(M) & 2(M) & 2(M) & 15 \\
\hline 9 & $\begin{array}{l}\text { Growth determinants in small } \\
\text { firms: drawing evidence from } \\
\text { the Indian agro-industry }\end{array}$ & (Panda, 2015) & $2(\mathrm{M})$ & $2(\mathrm{M})$ & $2(\mathrm{M})$ & $2(\mathrm{M})$ & 2(M) & $2(\mathrm{M})$ & 2(M) & 14 \\
\hline 10 & $\begin{array}{l}\text { The role of foreign direct } \\
\text { investment in the nutrition } \\
\text { transition }\end{array}$ & (Hawkes, 2005) & 2(M) & 2(M) & 2(M) & $2(\mathrm{M})$ & 2(M) & 2(M) & 2(M) & 14 \\
\hline 11 & $\begin{array}{l}\text { How strongly can industrial } \\
\text { structural transformation affect } \\
\text { GDP? }\end{array}$ & (Kodama, 2017) & $3(\mathrm{H})$ & $3(\mathrm{H})$ & $3(\mathrm{H})$ & $3(\mathrm{H})$ & 2(M) & $3(\mathrm{H})$ & 2(M) & 19 \\
\hline 12 & $\begin{array}{l}\text { Impact of Global Economic } \\
\text { Crisis on the Productivity } \\
\text { Performance of Agro-based } \\
\text { Industries in India: } \\
\text { A Malmquist DEA Approach }\end{array}$ & (Manonmani, 2015) & $3(\mathrm{H})$ & $3(\mathrm{H})$ & 2(M) & $2(\mathrm{M})$ & 2(M) & 2(M) & 2(M) & 16 \\
\hline 13 & $\begin{array}{l}\text { Is the development of the agro- } \\
\text { processing industry pro-poor? } \\
\text { The case of Thailand }\end{array}$ & $\begin{array}{l}\text { (Watanabe et al., } \\
\text { 2009) }\end{array}$ & $3(\mathrm{H})$ & $3(\mathrm{H})$ & $3(\mathrm{H})$ & $2(\mathrm{M})$ & 2(M) & $3(\mathrm{H})$ & $3(\mathrm{H})$ & 19 \\
\hline 14 & $\begin{array}{l}\text { Performance of Micro and } \\
\text { Small-Scale } \\
\text { (MSEs) in Tanzania: Growth } \\
\text { Hazards of Fruit and } \\
\text { Vegetables Processing } \\
\text { Vendors } \\
\end{array}$ & $\begin{array}{l}\text { (Mashimba \& Kühl, } \\
\text { 2014) }\end{array}$ & $3(\mathrm{H})$ & $3(\mathrm{H})$ & $3(\mathrm{H})$ & $3(\mathrm{H})$ & $3(\mathrm{H})$ & $2(\mathrm{M})$ & 2(M) & 19 \\
\hline 15 & 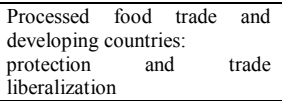 & (Rae \& Josling, 2003) & $2(\mathrm{M})$ & 2(M) & $3(\mathrm{H})$ & $2(\mathrm{M})$ & 2(M) & 2(M) & 2(M) & 15 \\
\hline 16 & $\begin{array}{l}\text { Innovation capabilities and } \\
\text { learning mechanisms: insights } \\
\text { from Ghanaian fresh fruit } \\
\text { processing enterprises }\end{array}$ & $\begin{array}{l}\text { (Osei-Amponsah, } \\
2020)\end{array}$ & $3(\mathrm{H})$ & 2(M) & 2(M) & $1(\mathrm{~L})$ & 2(M) & 2(M) & 2(M) & 14 \\
\hline 17 & $\begin{array}{l}\text { Modeling growth options and } \\
\text { structural change to reach } \\
\text { middle income country } \\
\text { status: The case of Ghana }\end{array}$ & $\begin{array}{l}\text { (Breisinger et al., } \\
\text { 2009) }\end{array}$ & 2(M) & $2(\mathrm{M})$ & $3(\mathrm{H})$ & $3(\mathrm{H})$ & 2(M) & $3(\mathrm{H})$ & $3(\mathrm{H})$ & 15 \\
\hline 18 & $\begin{array}{l}\text { Why agricultural production in } \\
\text { sub-Saharan Africa } \\
\text { remains low compared to the } \\
\text { rest of the world }- \text { a } \\
\text { historical perspective }\end{array}$ & $\begin{array}{l}\text { (Bjornlund et al., } \\
2020)\end{array}$ & $2(\mathrm{M})$ & 2(M) & 2(M) & $2(\mathrm{M})$ & 2(M) & 2(M) & 2(M) & 14 \\
\hline 19 & $\begin{array}{l}\text { Africa's stalled structural } \\
\text { transformation: the end } \\
\text { of the flying geese? }\end{array}$ & (Munyi, 2020) & $2(\mathrm{M})$ & 2(M) & 2(M) & $2(\mathrm{M})$ & 2(M) & 2(M) & 2(M) & 14 \\
\hline 20 & $\begin{array}{l}\text { Structural Transformation in } \\
\text { Africa: Static Gains, Dynamic } \\
\text { Losses }\end{array}$ & (De Vries et al., 2015) & 2(M) & 2(M) & 2(M) & 2(M) & 2(M) & 2(M) & $3(\mathrm{H})$ & 15 \\
\hline 21 & $\begin{array}{l}\text { The southern African poultry } \\
\text { value chain: Corporate } \\
\text { strategies, investments and } \\
\text { agro-industrial policies }\end{array}$ & (Ncube, 2018) & $2(\mathrm{M})$ & $3(\mathrm{H})$ & $3(\mathrm{H})$ & $3(\mathrm{H})$ & 2(M) & $3(\mathrm{H})$ & $3(\mathrm{H})$ & 20 \\
\hline 22 & $\begin{array}{lr}\text { The U.S. } & \text { Structural } \\
\text { Transformation and } & \text { Regional } \\
\text { Convergence: } & \text { A } \\
\text { Reinterpretation } & \\
\end{array}$ & $\begin{array}{l}\text { (Caselli \& Coleman } \\
\text { II, 2001) }\end{array}$ & $3(\mathrm{H})$ & $3(\mathrm{H})$ & $3(\mathrm{H})$ & $2(\mathrm{M})$ & 2(M) & 2(M) & 2(M) & 17 \\
\hline 23 & $\begin{array}{l}\text { ASEAN-CHINA Free Trade } \\
\text { Area: Advantages, Challenges, } \\
\text { and Implications for the newer } \\
\text { ASEAN Member countries }\end{array}$ & $\begin{array}{l}\text { (Wattanapruttipaisan, } \\
\text { 2003) }\end{array}$ & $3(\mathrm{H})$ & $3(\mathrm{H})$ & $3(\mathrm{H})$ & $3(\mathrm{H})$ & 2(M) & $3(\mathrm{H})$ & 2(M) & 19 \\
\hline
\end{tabular}




\begin{tabular}{|c|c|c|c|c|c|c|c|c|c|c|}
\hline $\begin{array}{c}\text { Item } \\
\# \\
\end{array}$ & Study Title & Author(s) & $\begin{array}{l}\text { Transparency } \\
\text { (T) }\end{array}$ & $\begin{array}{l}\text { Accuracy } \\
\text { (A) }\end{array}$ & $\begin{array}{l}\text { Purposivity } \\
\text { (P) }\end{array}$ & $\begin{array}{c}\text { Utility } \\
\text { (U) }\end{array}$ & $\begin{array}{l}\text { Propriety } \\
(\mathrm{P})\end{array}$ & $\begin{array}{l}\text { Accessibility } \\
\text { (A) }\end{array}$ & $\begin{array}{c}\text { Specificity } \\
(\mathrm{S})\end{array}$ & Score \\
\hline 24 & $\begin{array}{l}\text { Human-social capital and } \\
\text { market access factors } \\
\text { influencing agro-processing } \\
\text { participation by } \\
\text { small-scale agripreneurs: The } \\
\text { moderating effects of } \\
\text { transaction costs }\end{array}$ & $\begin{array}{l}\text { (Thindisa \& Urban, } \\
\text { 2018) }\end{array}$ & $3(\mathrm{H})$ & $2(\mathrm{M})$ & $3(\mathrm{H})$ & $2(\mathrm{M})$ & 2(M) & $3(\mathrm{H})$ & $2(\mathrm{M})$ & 17 \\
\hline 25 & $\begin{array}{l}\text { Unlocking the potentials of } \\
\text { Micro and Small } \\
\text { Enterprises (MSEs) in building } \\
\text { local technological } \\
\text { capabilities in agro-processing } \\
\text { industry }\end{array}$ & (Ahmad, 2020) & $3(\mathrm{H})$ & $3(\mathrm{H})$ & $3(\mathrm{H})$ & $2(\mathrm{M})$ & $3(\mathrm{H})$ & 2(M) & $3(\mathrm{H})$ & 19 \\
\hline 26 & $\begin{array}{l}\text { Agro-Processing Industry and } \\
\text { Farmers' Linkages: Pattern and } \\
\text { Impact on Enhancing Farmers' } \\
\text { Income in Tamil Nadu }\end{array}$ & $\begin{array}{l}\text { (Venkatesh et al., } \\
\text { 2017) }\end{array}$ & $3(\mathrm{H})$ & $3(\mathrm{H})$ & $3(\mathrm{H})$ & $3(\mathrm{H})$ & $2(\mathrm{M})$ & $2(\mathrm{M})$ & $3(\mathrm{H})$ & 20 \\
\hline 27 & $\begin{array}{l}\text { Agro-Processing Industries---A } \\
\text { Challenging Entrepreneurship } \\
\text { for Rural Development }\end{array}$ & (Shehrawat, 2006) & 2(M) & $2(\mathrm{M})$ & 2(M) & $2(\mathrm{M})$ & 2(M) & 2(M) & 2(M) & 14 \\
\hline 28 & $\begin{array}{c}\text { Does Agricultural Growth } \\
\text { Cause Manufacturing Growth? }\end{array}$ & (Shifa, 2015) & $2(\mathrm{M})$ & $3(\mathrm{H})$ & $3(\mathrm{H})$ & $2(\mathrm{M})$ & $2(\mathrm{M})$ & $2(\mathrm{M})$ & 2(M) & 16 \\
\hline 29 & $\begin{array}{l}\text { Challenges for agricultural } \\
\text { development in a resource-rich } \\
\text { developing country: a case } \\
\text { study of Papua New Guinea }\end{array}$ & (Sanida et al., 2016) & $3(\mathrm{H})$ & 2(M) & 2(M) & $2(\mathrm{M})$ & $2(\mathrm{M})$ & 2(M) & 2(M) & 15 \\
\hline 30 & $\begin{array}{c}\text { Economic growth, } \\
\text { convergence, and agricultural } \\
\text { economics }\end{array}$ & (Martin, 2019) & $3(\mathrm{H})$ & $3(\mathrm{H})$ & $3(\mathrm{H})$ & $3(\mathrm{H})$ & 2(M) & $3(\mathrm{H})$ & 2(M) & 19 \\
\hline 31 & $\begin{array}{l}\text { Productivity For Agro-Based } \\
\text { Industrial Sub-Sector in } \\
\text { Malaysia Using Malmquist } \\
\text { Index }\end{array}$ & (Ruslan, 2018) & 2(M) & 2(M) & 2(M) & $2(\mathrm{M})$ & 2(M) & 2(M) & 2(M) & 14 \\
\hline
\end{tabular}

Appendix C: Example line-by-line coding of text from an included article

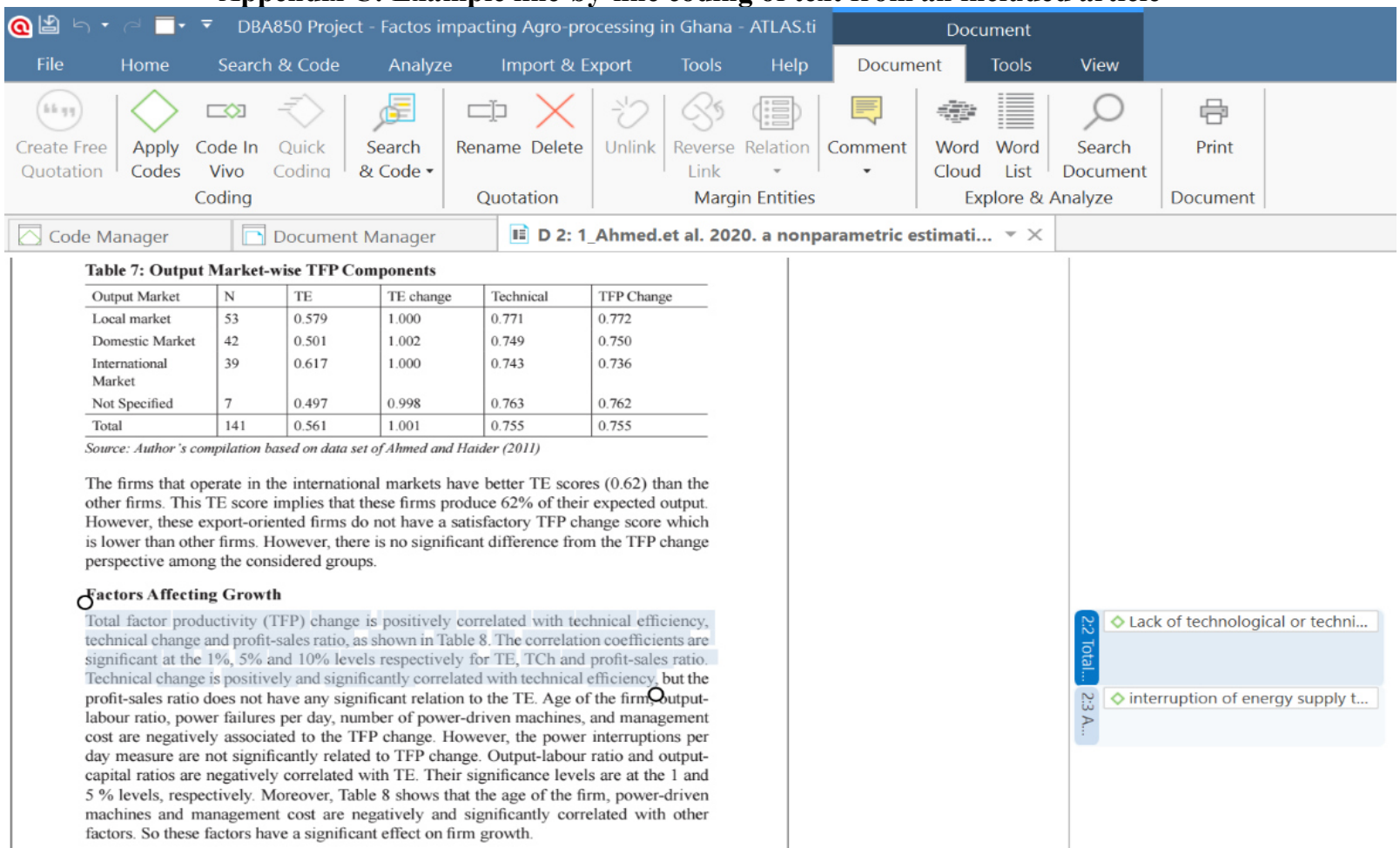

Note. This is a screenshot example of using ATLAS.ti software version 9.1.6.0 to do line-by-line coding of included articles. 


\section{Appendix D: Example hierarchical network diagram of a codeword linked to its sample quotations}

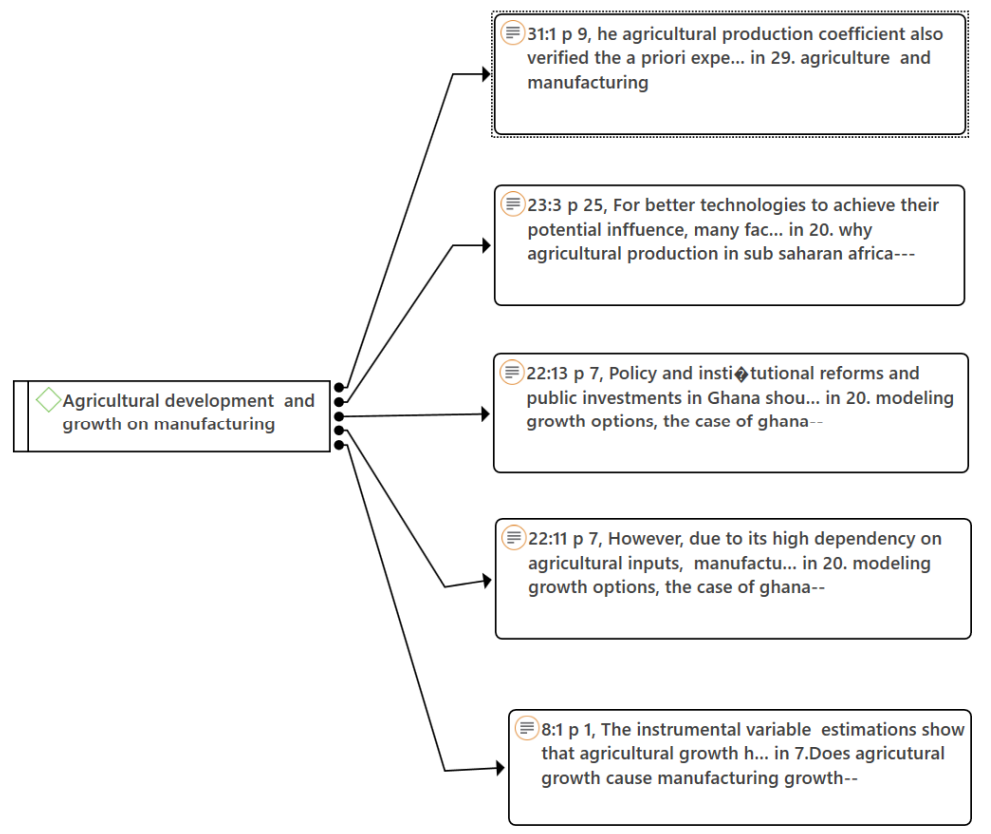

Note. This is a representation of a codeword linked to quotations from the different included articles, generated using ATLAS.ti software.

\section{Appendix E: An example generation of a descriptive theme from codewords}

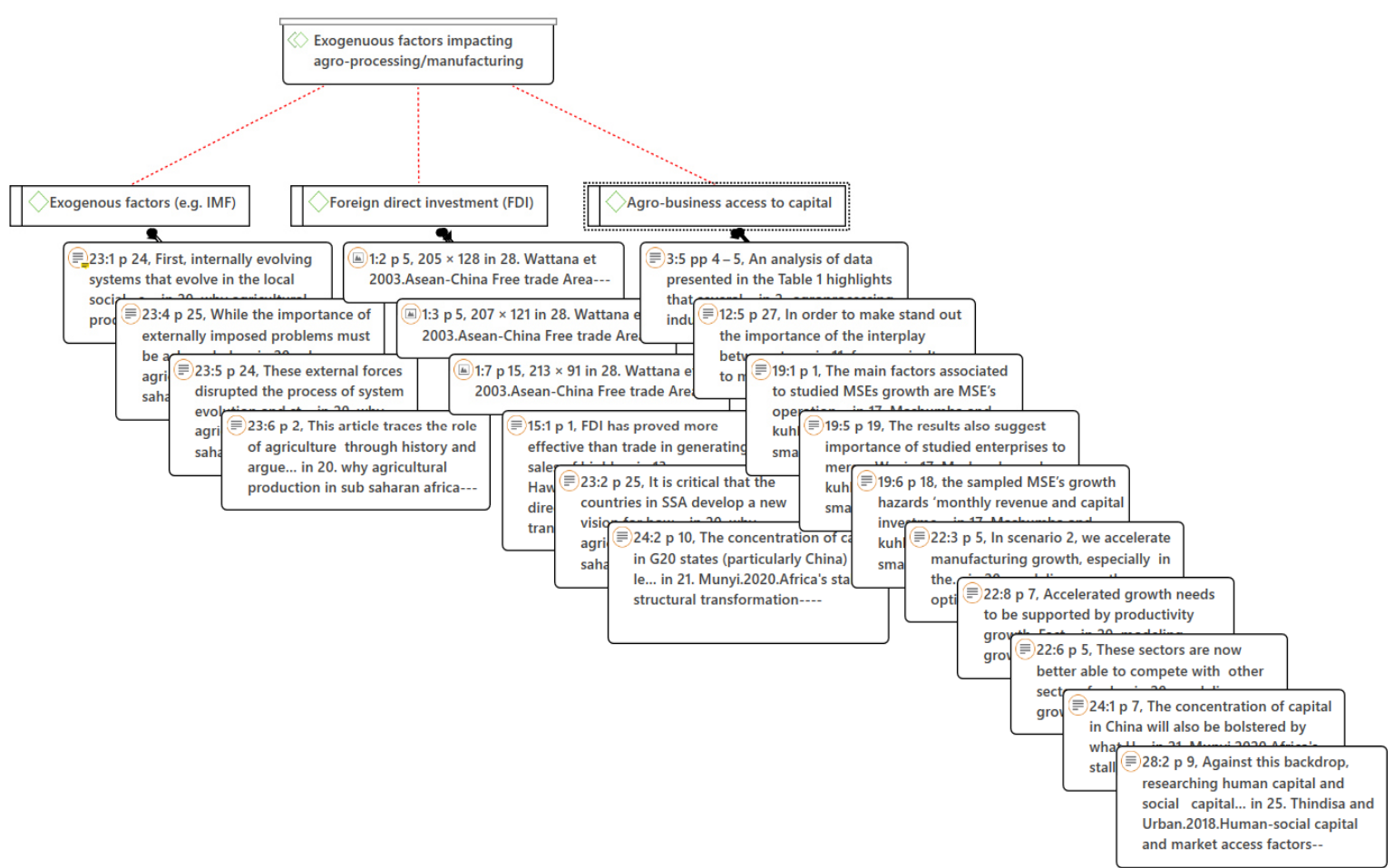

Note. An example network diagram generated from ATLAS.ti. software version 9.1.6.0. Its shows how the descriptive theme "Exogenous factors impacting agro-processing/manufacturing" and its link to the 3 primary codes coupled with samples of supporting quotes. 


\section{Appendix F: An example generation of an analytical theme}

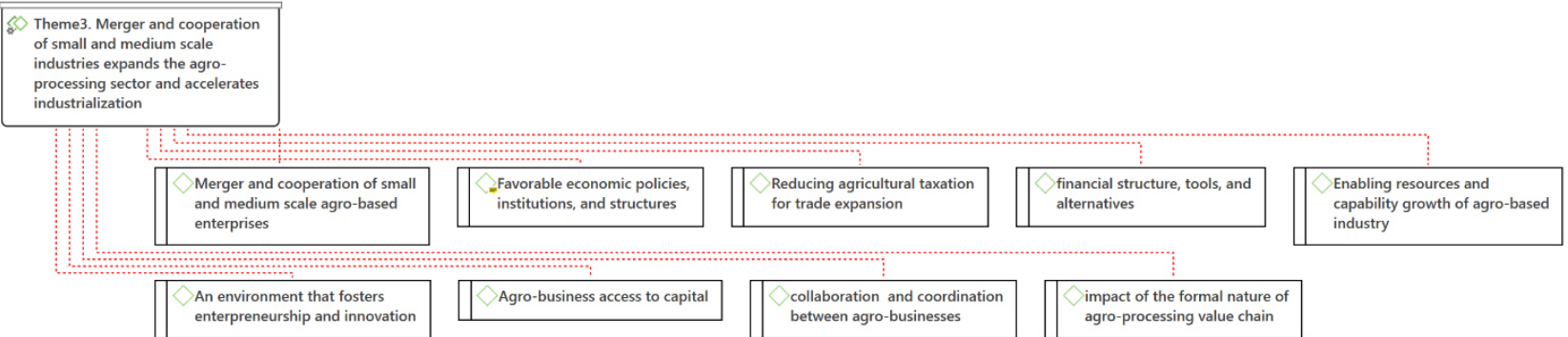

Note. An example network diagram showing a linkage between analytical theme \# 3 and primary codes. Network diagram generated using ATLAS.ti software version 9.1.6.0

\section{Appendix G: Analysis of the formation of 'Analytical themes' from primary codes and descriptive themes}

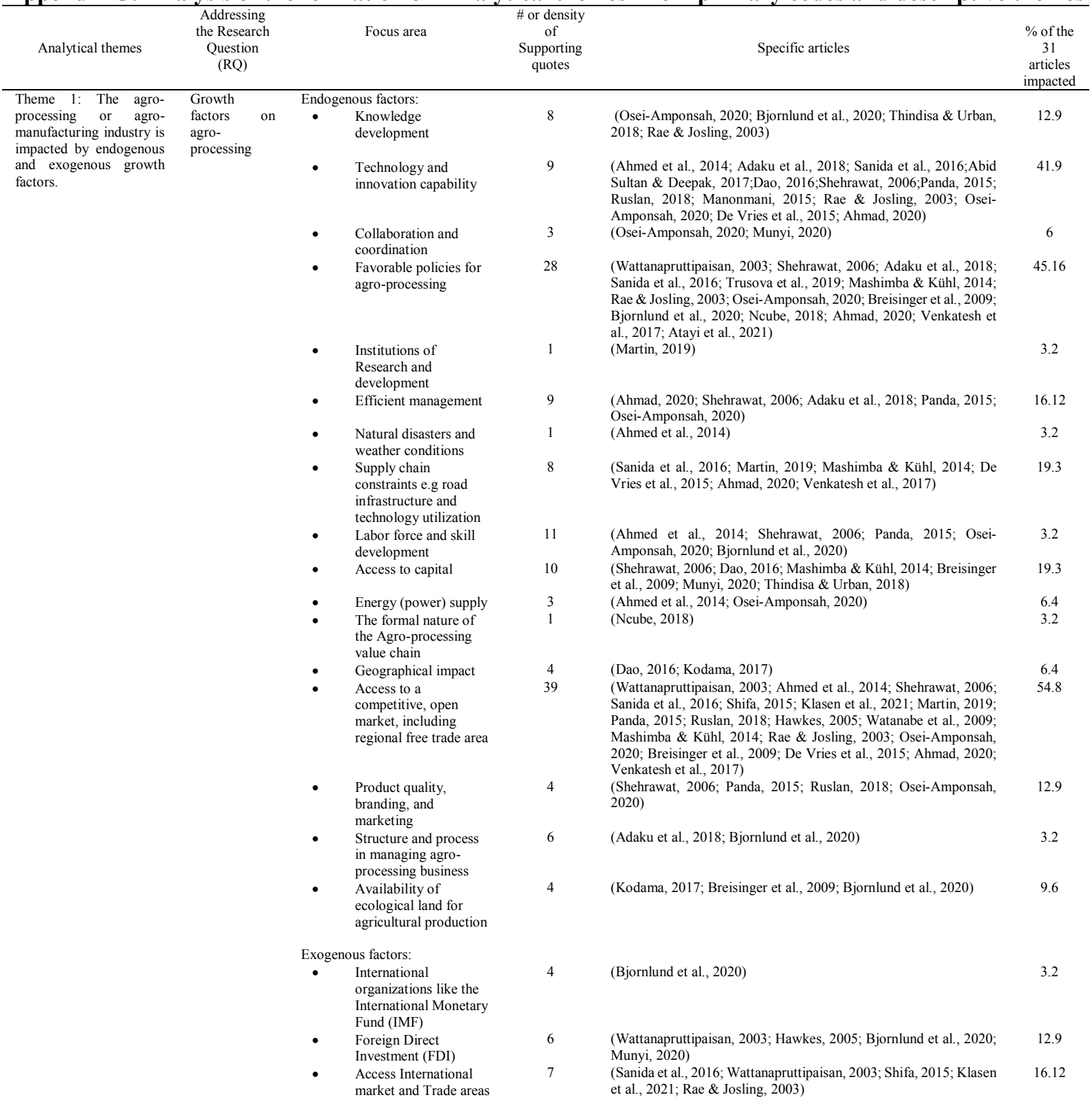




\begin{tabular}{|c|c|c|c|c|c|}
\hline Analytical themes & $\begin{array}{l}\text { Addressing } \\
\text { the Research } \\
\text { Question } \\
\text { (RQ) }\end{array}$ & Focus area & $\begin{array}{l}\text { \# or density } \\
\quad \text { of } \\
\text { Supporting } \\
\text { quotes }\end{array}$ & Specific articles & $\begin{array}{l}\% \text { of the } \\
31 \\
\text { articles } \\
\text { impacted }\end{array}$ \\
\hline $\begin{array}{l}\text { Theme 2: Governments } \\
\text { should focus on smart } \\
\text { economic policies, } \\
\text { regulations, and funding } \\
\text { mechanism r that } \\
\text { accelerates agro- } \\
\text { processing/manufacturing } \\
\text { industrialization }\end{array}$ & $\begin{array}{l}\text { Merger and } \\
\text { cooperation of } \\
\text { small and } \\
\text { medium scale } \\
\text { enterprises. }\end{array}$ & $\begin{array}{l}\text { Promoting a policy-driven } \\
\text { business environment that } \\
\text { enables easy funding of agro- } \\
\text { processing }\end{array}$ & 47 & $\begin{array}{l}\text { Shehrawat, 2006; Dao, 2016; Mashimba \& Kühl, 2014; Breisinger } \\
\text { et al., 2009; Munyi, 2020; Thindisa \& Urban, 2018; } \\
\text { Wattanapruttipaisan, 2003; Osei-Amponsah, 2020; Munyi, 2020; } \\
\text { Mashimba \& Kühl, 2014; Adaku et al., 2018; Sanida et al., 2016; } \\
\text { Trusova et al., 2019; Rae \& Josling, 2003; Bjornlund et al., 2020; } \\
\text { Ncube, 2018; Ahmad, 2020; Venkatesh et al., 2017; Atayi et al., } \\
\text { 2021) }\end{array}$ & 54.8 \\
\hline $\begin{array}{l}\text { Theme 3: Merger and } \\
\text { cooperation of small and } \\
\text { medium scale industries } \\
\text { expands the agro- } \\
\text { processing sector and } \\
\text { accelerates } \\
\text { industrialization }\end{array}$ & $\begin{array}{l}\text { Expansion of } \\
\text { the agro- } \\
\text { processing } \\
\text { industries } \\
\text { expands } \\
\text { manufacturing } \\
\text { value add. }\end{array}$ & $\begin{array}{l}\text { Scaling and expansion of agro- } \\
\text { processing industries through } \\
\text { merger and cooperation of small } \\
\text { and medium scale business }\end{array}$ & 2 & (Mashimba \& Kühl, 2014; Venkatesh et al., 2017) & 3.2 \\
\hline $\begin{array}{l}\text { Theme 4: Increased } \\
\text { agricultural productivity } \\
\text { causes continuous growth } \\
\text { in agro- } \\
\text { processing/manufacturing }\end{array}$ & $\begin{array}{l}\text { continuous } \\
\text { growth in the } \\
\text { agro- } \\
\text { processing } \\
\text { sector }\end{array}$ & $\begin{array}{l}\text { Sustained Agricultural } \\
\text { productivity ensures continuous } \\
\text { growth in the agro-processing } \\
\text { sector. }\end{array}$ & 33 & $\begin{array}{l}\text { (Shifa, 2015; Breisinger et al., 2009; Bjornlund et al., 2020; Atayi } \\
\text { et al., 2021; Dorosh \& Thurlow, 2018; Sanida et al., 2016; Abid } \\
\text { Sultan \& Deepak, 2017; Panda, 2015; Watanabe et al., 2009; } \\
\text { Mashimba \& Kühl, 2014; Rae \& Josling, 2003; Breisinger et al., } \\
\text { 2009; Munyi, 2020; De Vries et al., 2015; Caselli \& Coleman II, } \\
\text { 2001; Thindisa \& Urban, 2018; Venkatesh et al., 2017; Atayi et al., } \\
\text { 2021) }\end{array}$ & 54.8 \\
\hline $\begin{array}{l}\text { Theme 5: Increased and } \\
\text { continuous access to } \\
\text { international trading } \\
\text { markets and demand- } \\
\text { driven exports of agro- } \\
\text { manufactured boosts } \\
\text { economic growth }\end{array}$ & $\begin{array}{l}\text { Economic } \\
\text { growth (GDP } \\
\text { growth) }\end{array}$ & $\begin{array}{l}\text { International trade and exports of } \\
\text { agro-based } \quad \text { manufactured } \\
\text { products }\end{array}$ & 11 & $\begin{array}{l}\text { (Dao, 2016; Kodama, 2017; Klasen et al., 2021; Hawkes, 2005; } \\
\text { Sanida et al., 2016; Wattanapruttipaisan, 2003; Shifa, 2015; Rae \& } \\
\text { Josling, 2003) }\end{array}$ & 3.2 \\
\hline $\begin{array}{l}\text { Theme 6: Enhancement of } \\
\text { local value chain } \\
\text { mechanisms through } \\
\text { policy, efficient } \\
\text { management, branding, } \\
\text { and packaging of agro- } \\
\text { processed/manufactured } \\
\text { products can boost } \\
\text { economic growth. }\end{array}$ & $\begin{array}{l}\text { Economic } \\
\text { growth }\end{array}$ & $\begin{array}{l}\text { Favorable economic policies, } \\
\text { efficient management agro- } \\
\text { processing firms, packaging, } \\
\text { branding, and marketing of agro- } \\
\text { manufactured products }\end{array}$ & 22 & $\begin{array}{l}\text { (Wattanapruttipaisan, 2003; Shehrawat, 2006; Adaku et al., 2018; } \\
\text { Sanida et al., 2016; Trusova et al., 2019; Mashimba \& Kühl, 2014; } \\
\text { Rae \& Josling, 2003; Osei-Amponsah, 2020; Breisinger et al., 2009; } \\
\text { Bjornlund et al., 2020; Ncube, 2018; Ahmad, 2020; Venkatesh et } \\
\text { al., 2017; Atayi et al., 2021; Panda, 2015; Ruslan, 2018) }\end{array}$ & 48.38 \\
\hline $\begin{array}{l}\text { Theme 7: Access to } \\
\text { foreign direct investment } \\
\text { and government funding } \\
\text { to the agro-industrial } \\
\text { sector is an economic } \\
\text { development accelerator }\end{array}$ & $\begin{array}{l}\text { Economic } \\
\text { growth and } \\
\text { structural } \\
\text { transformation }\end{array}$ & $\begin{array}{l}\text { FDI can directly accelerate } \\
\text { funding of the agro-industrial } \\
\text { complex }\end{array}$ & 20 & $\begin{array}{l}\text { (Shehrawat, 2006; Dao, 2016; Mashimba \& Kühl, 2014; Breisinger } \\
\text { et al., 2009; Munyi, 2020; Thindisa \& Urban, 2018; Bjornlund et } \\
\text { al., 2020; Wattanapruttipaisan, 2003; Hawkes, 2005; Munyi, 2020) }\end{array}$ & 32.25 \\
\hline
\end{tabular}

\section{Appendix H: Comparison of Ghana and other Advanced and Developed Countries}

\begin{tabular}{|c|c|c|}
\hline Category & $\begin{array}{l}\text { Growth } \\
\text { factors }\end{array}$ & The situation in developing countries like Ghana \\
\hline \multirow[t]{3}{*}{$\begin{array}{l}\text { Endogenous } \\
\text { factors }\end{array}$} & $\begin{array}{l}\text { Knowledge } \\
\text { management }\end{array}$ & $\begin{array}{l}\text { This study found that small and medium-scale agro-processing companies } \\
\text { often lack or do not adequately enforce informal and context-specific } \\
\text { approaches to learning and learning-by-doing techniques. There are often few } \\
\text { or limited research institutions for knowledge development and management. } \\
\text { Continuous human capital development through skill training and capacity } \\
\text { building are at their low ends. Knowledge development, though the robustness } \\
\text { is often questionable, occurs at a few universities and research institutions such } \\
\text { as the CSIR, Cocoa Research Institute (CRIG), and the Ministry of Food and } \\
\text { Agriculture (MOFA). Knowledge management leads to improvement in } \\
\text { organizational efficiency (Njuguna \& Wanjohi, 2021; Osei-Amponsah, 2020; } \\
\text { Bjornlund et al., 2020; Thindisa \& Urban, 2018; Rae \& Josling, 2003; Tandoh- } \\
\text { Offin, 2011) }\end{array}$ \\
\hline & $\begin{array}{l}\text { Technology } \\
\text { and } \\
\text { innovation } \\
\text { capability }\end{array}$ & $\begin{array}{l}\text { This study asserted the need for investment in technology and innovation hubs } \\
\text { formulated on a bedrock of sound and favorable economic policies that } \\
\text { promote agro-processing entrepreneurship. Asare \& Essegbey ( } 2016) \\
\text { confirmed and recommended the commercialization of technology } \\
\text { development, innovation capability, and government investment. There is a } \\
\text { need to move away from only niche-specific and internet-based knowledge } \\
\text { acquisition to a more formal and institutional capacity building founded on a a } \\
\text { bedrock of deliberate and effective technology utilization (Ahmed et al., aht; } \\
\text { 2014;Adaku et al., 2018; Sanida et al., 2016;Abid Sultan \& Deepak, 2017; } \\
\text { (Dao, 2016;Shehrawat, 2006;Panda, 2015;Ruslan, 2018;Manonmani, } \\
2015 \text {;Rae \& Josling, 2003, Osei-Amponsah, 2020, De Vries et al., 2015, } \\
\text { Ahmad, 2020). }\end{array}$ \\
\hline & $\begin{array}{l}\text { Collaboration } \\
\text { and } \\
\text { coordination }\end{array}$ & $\begin{array}{l}\text { Ghana to create a business-friendly environment that encourages collaboration } \\
\text { and coordination between especially small and medium scale agro-enterprises } \\
\text { on products, markets, etc. (Osei-Amponsah, 2020) (Munyi, 2020). The dying } \\
\text { process to agro-industrial growth and capability advancement to be } \\
\text { encouraged }\end{array}$ \\
\hline
\end{tabular}

According to Mckinsey survey report, executives from 40 companies in Europe, Japan, and United States believed that knowledge management began with building sophisticated information technology systems and linking all the information together to create models/strategies that, for example, increases together to create models/strategies tha, for example, increases profitability through the process, products, and customer
relationship improvements (Hauschild et al, 2001). Agrorelationship improvements (Hauschild et al., 2001). Agroprocessing companies may have to avoid a top-down approach to knowledge sharing and embrace knowledge pull from employees to build winning strategies. Europeans encourage and fund crossnational networking in research (Boonekamp et al., 1998). Small
holder agro-business need to invest in training to increase the holder agro-business need to invest in training to increas
knowledge base of the organization (Melembe et al., 2021) China in the mid-1980s invested heavily in advanced technologies and innovation in most of its agro-processing enterprises, leading to its scaling and competitiveness in the market (OECD, 2000).

International networking and collaborative efforts among firms are encouraged, as well as among research centers and organizations encorions (Boonekanp et al., 1998). Considering that small firms are more similar than diferent in many countries, developed nations understand the die process of networking and how activities and their effectiveness contribute to enterprise growth and die thickening of die industrial base - a dynamic that can be replicated in developing countries (Mcdade \& Malecki, 2008). 


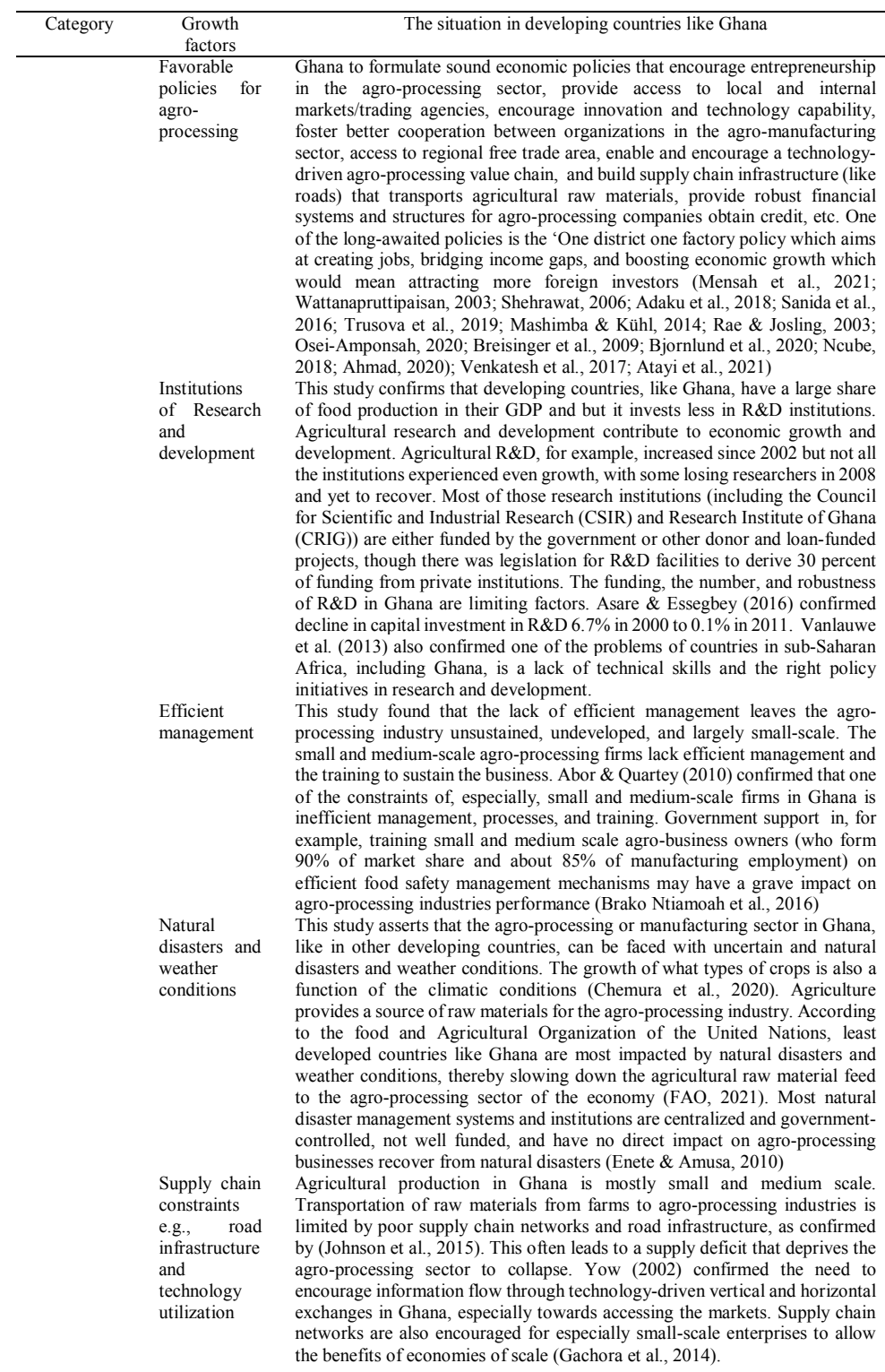

Labor force Agro-processing and manufacturing industries should invest in continuous and skill technical efficiency and technology know-how of their labor force. Training is development confirmed to be essential to labor force skill development especially for small and medium agro-processing enterprises (Johnson et al., 2015; Melembe et al., 2021).

Access capital

Energy (power) supply

The formal nature of the Agroprocessing value chain
Geographical impact to This study asserts that small and medium scale agro-industries require access to operational capital and credit to help in technology and innovation capability building and scaling

The agro-processing sector utilizes a lot of power-driven machines. A reliable power supply is a requirement for continuous operation and agro-business performance. Adarkwah \& Nyanzu (2016) also confirmed that power supply interruptions are a problem that affects the performance of small and medium
scale enterprises, not limited to agro-processing industries. Mehetre (2010) scale enterprises, not limited to agro-processing industries. Mehetre (2010)
also confirmed that unreliable power supply is one of many challenges faced also confirmed that unreliable

by the agro-processing sector.
Formalization of the structures within the agro-processing value chain is a key growth factor.

Ghana, a developing country, in sub-Saharan Africa is located in ecological geography that allows agricultural production. This can quickly become a
disadvantage and delay the timing for manufacturing growth if deliberate and formal approaches are not adopted. There is a need for deliberate plans about the timing, geography, and growth of the agro-industry.
The developed and emerging economies

Policies in advanced economies, like China, do not only

emphasize agro-processing production output but the quality of processing and products as well (OECD, 2000). Some of the policies are focused on collaborative research across various academic and industrial institutions organizations (Boonekamp et al., 1998). According to Norman \& Stiglitz (2017), diffusion policies facilitate dynamic efficiency, especially, those that encourage and push for innovation and technological advancement across the industrial complex is promoted.

Advanced countries ensure increased advocacy for research and development in many institutions (Augusto, 2000), which includes agro-processing industries. Countries like Japan, those in Europe, and the United States apply FDI to building new R\&D infrastructures and explore firm-specific advantages that lead to economic growth and development (Kuemmerle,1999).

Efficient management is critical to ensuring value extraction from agro-processing value chain processing. Ajila et al. (2012) confirmed that efficient management practices ensured that $\sim 44 \%$ confirmed that efficient management practices ensured that $\sim 44 \%$
of solid waste is recycled in developed countries. According to Santacoloma et al.(2009) at the Food and Agriculture Organization Santacoloma et al.(2009) at the Food and Agriculture Organization
(FAO) of the United Nations, Hazard Analysis Critical Control (FAO) of the United Nations, Hazard Analysis Critical Control
Point (HACCP) system is an example of an efficient management Point (HACCP) system is an example of an efficient manageme
mechanism that developed nations use for efficient food safety

Most institutions for natural disaster management in industrialized countries are well funded and mostly owned by the private sector, which has a direct impact on agro-processing industries. Japan, for instance, uses a bottom-top management system where 13 national research institutes are connected with 255 prefectural research institutes who have direct links with agribusiness without influence by national officers, allowing the direct touch and accountability to agro-businesses impacted in case of natural disasters (Enete \& Amusa, 2010)

Developed nations, like the United States, Japan, etc. ensures coordination between all supply chain partners to give way for economic growth (Ojo et al., 2018). The road infrastructure in developed countries is well developed to allow for continuous and developed countries is well developed to allow for continuous and
uninterrupted competitive economic activities though the uninterrupted competive economic activities though the occupation of land for road transport development is occurring at a
pace that is a direct threat to other economic factors like food, and pace that is a direct threat to other economic factors like food, and
tourism (Prus \& Sikora, 2021). Transport policy is an accelerator of tourism (Prus \& Sikora, 2021). Transport policy is an accelerator of
sustainable economic growth and development through road sustainable economic grow
infrastructural development.

Developed countries, like Japan, etc., use specialized agencies of the United Nations that promote industrial and skill development, The UNIDO-Japan-UNIDO encouraged the member states to identify and apply sustainable solutions to industrial skills development by strategically partnering with private, public, and development partners. United States has the beginning farmer and rancher development program that provides grants to educate and train new agro-business owners on legal, business management, production, etc. (U.S Department of Agriculture, n.d.)

The United States, for example, has favorable policies like the recent Farm Storage Facility Loan (FSFL) for food storage and recent Farm Storage Facility Loan (FSFL) for food storage and related equipment. The United States also launched the microloan program which allowed small and medium scale farmers to access
loans up to $\$ 35,000$ after completion of a simple application process (U.S Department of Agriculture, n.d.)

Developed countries are investing in alternate and renewable Developed countries are investing in alternate and renewable
sources of energy for various industries. The United States has various policy strategies that focus on, for example, modernizing rural electric infrastructure (where agricultural production is massive) (U.S Department of Agriculture, n.d.)

Economic and social upgrades caused by agro-industrialization requires a form of formalization of all value chain processes (Pasquali et al., 2021)

The geographical location of the agro-processing cluster improved the performance of agro-processing firms. The geographical dispersion of agro-processing firms has an impact on the market performance (Huang \& Xiong, 2018) 


\begin{tabular}{|c|c|c|c|}
\hline Category & $\begin{array}{l}\text { Growth } \\
\text { factors }\end{array}$ & The situation in developing countries like Ghana & The developed and emerging economies \\
\hline & $\begin{array}{l}\text { Access to a } \\
\text { competitive, } \\
\text { open market, } \\
\text { including } \\
\text { regional free } \\
\text { trade area }\end{array}$ & $\begin{array}{l}\text { Easy access to an open, even, and competitive marketplace allows agro- } \\
\text { processing industries to thrive and drives the sustained sale of agro- } \\
\text { manufactured products. }\end{array}$ & $\begin{array}{l}\text { Advanced economies like the United States is open for open } \\
\text { markets, serve as a catalyst of wider trade agreements, support } \\
\text { domestic market-oriented reformers, and strengthen strategic } \\
\text { partnerships, etc. (Huang \& Xiong, 2018) }\end{array}$ \\
\hline & $\begin{array}{l}\text { Product } \\
\text { quality, } \\
\text { branding, and } \\
\text { marketing }\end{array}$ & $\begin{array}{l}\text { All Agro-processing businesses in all developing countries, including Ghana, } \\
\text { either small, medium, and large-scale enterprises, to invest in competitive } \\
\text { product quality, enhanced and technology-driven marketing and branding } \\
\text { strategies that drive sales and relevance in the marketplace. }\end{array}$ & $\begin{array}{l}\text { Japan leads the way in the global market with high-technology and } \\
\text { innovative products while United States industries are known for } \\
\text { breakthrough research (Huang \& Xiong, 2018) }\end{array}$ \\
\hline & $\begin{array}{l}\text { Structure and } \\
\text { process in } \\
\text { managing the } \\
\text { agro- } \\
\text { processing } \\
\text { business }\end{array}$ & $\begin{array}{l}\text { Properly managing a successful agro-processing firm, especially small and } \\
\text { medium scale, requires the institution of formal operational structure and } \\
\text { process, including project management techniques and the continuation of } \\
\text { project teams. }\end{array}$ & $\begin{array}{l}\text { The United States, like other developed countries, ensures good } \\
\text { business process engineering with proper project and management } \\
\text { practices born on knowledge, information technology capabilities. } \\
\text { (Njuguna \& Wanjohi, 2021) }\end{array}$ \\
\hline & $\begin{array}{l}\text { Availability } \\
\text { of ecological } \\
\text { or arable land } \\
\text { for } \\
\text { agricultural } \\
\text { production }\end{array}$ & $\begin{array}{l}\text { The growth factor for sustained agricultural production is Land. Continuous } \\
\text { agricultural production serves raw materials to the agro-manufacturing sector. } \\
\text { The lack of land access is a limiting factor to sustainable agro-processing and } \\
\text { increased manufacturing value-add }\end{array}$ & $\begin{array}{l}\text { Developing and emerging economies are invested in arable lands. } \\
\text { The United States is the world's largest economy in arable land area } \\
\text { and is closely followed by India and China. China since the 1990s } \\
\text { has become the largest country in the area of permanent crops, an } \\
\text { agricultural area, followed by Australia, the United States, and India } \\
\text { which allows agro-processing (Zhang \& Liu, 2017). }\end{array}$ \\
\hline \multirow[t]{3}{*}{$\begin{array}{l}\text { Exogenous } \\
\text { factors }\end{array}$} & $\begin{array}{l}\text { International } \\
\text { organizations } \\
\text { like the } \\
\text { International } \\
\text { Monetary } \\
\text { Fund (IMF) }\end{array}$ & $\begin{array}{l}\text { It is important for developing countries, like Ghana, to be careful in their } \\
\text { partnership with external agencies like the IMF. It is critical to minimize } \\
\text { external control and manipulation while promoting internal and organic } \\
\text { growth by leveraging relevant internal (or local) institutions. }\end{array}$ & $\begin{array}{l}\text { United States is the largest shareholder of the IMF. A borrowing } \\
\text { country voting pattern in UN general assembly makes a huge } \\
\text { impact. Countries who visited with the United States received fewer } \\
\text { conditions. Otherwise, it would receive loans with more conditions } \\
\text { (Dreher \& Jensen, 2007). Developed countries do not suffer the } \\
\text { consequences of inequality that IMF borrowing inflicts on its } \\
\text { citizenry, coupled with the constraints of distributional preferences } \\
\text { in that country (Lang, 2020) }\end{array}$ \\
\hline & $\begin{array}{l}\text { Foreign } \\
\text { Direct } \\
\text { Investment } \\
\text { (FDI) }\end{array}$ & $\begin{array}{l}\text { This study proves that FDI could help accelerate infrastructural development } \\
\text { agro-based industrialization. It can help agro-processing industries find } \\
\text { leverage and gain power for efficient and unlimited marketing and distribution } \\
\text { of agro-manufacture products. Also, Abor et al. (2008) confirmed that FDI can } \\
\text { help Ghana to explore and promote its export performance of products, which } \\
\text { would include agro-manufactured products. Hence policy initiatives are } \\
\text { encouraged to allow of easy inflow FDIs into the country. Ghana's 'One } \\
\text { District One Factory' policy is strategic to pull in FDI for economic and } \\
\text { structural development (Mensah et al., 2021) }\end{array}$ & $\begin{array}{l}\text { Kuemmerle (1999) concluded that firms in advanced countries like } \\
\text { Japan, Europe, and the United States use FDI to build new or } \\
\text { explore firm-specific advantages in R\&D and associated } \\
\text { infrastructure. This exploration will not be limited to agro- } \\
\text { manufactured firms and products. }\end{array}$ \\
\hline & $\begin{array}{l}\text { Access to } \\
\text { international } \\
\text { markets, and } \\
\text { trade, an } \\
\text { export } \\
\text { opportunities }\end{array}$ & $\begin{array}{l}\text { International trade and export opportunities agreement to market and sell agro- } \\
\text { processed/manufactured products. Economies that are more open to trade } \\
\text { allow growth in agricultural production, which easily translates to agro- } \\
\text { processing and manufacturing growth. Trades in most, if not all, agro- } \\
\text { processed foods occur in developed countries and are dominated by a few } \\
\text { multinational firms (Asokan \& Singh, 2003). The free trade area is an } \\
\text { important strategic asset for developing countries. China, the largest } \\
\text { developing economy, has free trade arrangements with ASEAN - countries } \\
\text { (Cambodia, Laos, Myanmar, and Vietnam)(Wattanapruttipaisan, 2003). } \\
\text { Likewise, Ghana has recently joined the AfCFTA (African Continental Free } \\
\text { Trade Area), the largest trade organization in history, to allow trade } \\
\text { partnerships with its fellow African countries and international markets in } \\
\text { agricultural and related agro-processed or manufactured products. Ghana, } \\
\text { through the trade and investment framework agreement (NITA) with the } \\
\text { United States, is the } 83^{\text {rd }} \text { largest goods trading partner of the United States, } \\
\text { exporting agricultural and agro-processed products with leading categories } \\
\text { such as cocoa beans, cocoa paste \& cocoa butter, rubber \& allied products, } \\
\text { fresh vegetables ( } \$ 13 \text { million), and other vegetable oils, to the United States } \\
\text { (United States Trade Representative, n.d.). More of such strategic partnerships } \\
\text { are to be encouraged. }\end{array}$ & $\begin{array}{l}\text { Developed countries, like the United States, typically dictate the } \\
\text { exacting standards of quality for agro-processed products from } \\
\text { developing countries, an implication that developing countries need } \\
\text { to establish lasting relationships with developed countries (Asokan } \\
\text { \& Singh, 2003). Developed countries are aligned to making } \\
\text { arrangements for Free Trade policies (Feinberg, 2003). According } \\
\text { to the Office of the United States Trade Representative (n.d.), the } \\
\text { United States has free trade arrangement with about } 20 \text { countries } \\
\text { namely Australia, Bahrain, Canada, Chile, Colombia, Costa Rica, } \\
\text { Dominican, Republic, El Salvador, Guatemala, Honduras, Israel, } \\
\text { Jordan, Korea, Mexico, Morocco, Nicaragua, Oman, Panama, Peru, } \\
\text { Singapore, and the US-Mexico Canada agreement. }\end{array}$ \\
\hline
\end{tabular}

